\title{
Non-Linearity Between Life Insurance and Economic Development: A Revisited Approach
}

\author{
Chi-Hung Chang and Chien-Chiang Lee \\ Department of Finance, National Sun Yat-Sen University, Kaohsiung, Taiwan. \\ E-mail: cclee@cm.nsysu.edu.tw
}

This paper investigates the non-linear link between economic development and activities of the life insurance market. We ask whether the relevance of institutional environments on the development of the life insurance market is different across countries. Applying a novel threshold model with the instrumental variable approach, we find overwhelming evidence in support of an income threshold. Moreover, legal and political circumstances have an overwhelming positive effect on life insurance in low-income countries, but the effect is marginal in high-income countries. Our findings clearly demonstrate that the role of institutions on activities in the life insurance market diminishes with the evolvement of economic development.

The Geneva Risk and Insurance Review (2012) 37, 223-257. doi:10.1057/grir.2011.10; published online 20 December 2011

Keywords: life insurance; economic development; institutions; threshold regression; non-linearity.

\section{Introduction}

The importance of legal and political environments on economic and financial development has been deeply investigated, but does not attract much attention in the insurance community. ${ }^{1}$ The fact that insurance is a kind of contractual relationship implies that legal rules should influence the development of the insurance market, for example, the protection of property rights and regulations on the rights and obligations of both parties in the contract. To some extent, whether the legal system is sound and whether legal rules can be implemented stringently depend on the political environments, for example, political stability or a corrupt situation. Consequently, both legal and political environments should matter for the development of the insurance market.

Some studies have recognised that insurance market activities may vary across countries, because of the differences in economic performance,

\footnotetext{
${ }^{1}$ Ward and Zurbruegg (2002); Beck and Webb (2003); Esho et al. (2004).
} 
socio-cultural background, and other national circumstances. The argument has identified that the effect of an income increase on the demand for insurance varies as the economy matures. A crucial question naturally arises as to whether the effect of institutions on the insurance market is also divergent for different stages of economic development. This article attempts to address this topic by using an advanced threshold regression framework that distinguishes countries with different levels of economic development on a sample-based basis.

We proceed with our research via two steps. First, we employ a threshold technique with the instrumental variables to endogenously divide countries into groups with different levels of economic development measured by real GDP per capita. Our samples consist of a pooling data of 92 economies (Appendix A) with real GDP per capita (in 2,000 US dollars) ranging from US\$367.48 to US\$48,485.34 over the period 1996-2008. ${ }^{2}$ Second, we investigate whether the effect of real income and institutions on life insurance development varies under different levels of economic development. If exceptions do exist, then it may not be possible to form a general consensus applicable to all countries. This would mean that certain conditions must be modified and that other pre-conditions be met before a country conforms to any one universal consensus.

The development of the insurance market should not be ignored because, like the banking sector and stock market, it plays an important role in promoting economic growth. However, the view about the effect of banking development on economic growth is still divergent, including a positive effect, ${ }^{3}$ no effect, ${ }^{4}$ and even a negative effect, ${ }^{5}$ but studies have documented that the effect of insurance development on economic growth is mostly positive. ${ }^{6}$ The difference may be due to the potential complementary effect between the insurance sector and the stock market, as opposed to the substitution effect of the banking sector. ${ }^{7}$ Moreover, life insurance should play a more important role than non-life insurance, because long-term funds it provides are more relevant to capital markets' development.

Most existant studies use a conventional linear model to examine the relationship between economic development and insurance activities and assume that a different degree of economic development has uniform effects on

\footnotetext{
${ }^{2}$ Our sample includes entities that are not fully independent (e.g., Hong Kong). For convenience, all 92 entities are referred to in this paper as "countries", and countries and economic entities are used interchangeably (see Appendix A).

${ }^{3}$ King and Levine (1993); Levine (1997); Levine and Zervos (1998).

${ }^{4}$ Atje and Jovanovic (1993); Levine and Zervos (1996).

${ }^{5}$ Shen and Lee (2006); Lee (2011).

${ }^{6}$ Ward and Zurbruegg (2000); Webb et al. (2002); Han et al. (2010).

${ }^{7}$ Arestis et al. (2001); Lee (2011).
} 
insurance activities. However, at different stages of economic development, income level or relevant macroeconomic variables may have different effects on the insurance market activities. Carter and Dickinson ${ }^{8}$ and Enz ${ }^{9}$ develop a logistic model to characterise the relationship between insurance penetration and GDP per capita, which is called "the S-curve model" due to the shape of the letter "S". The S-curve pattern implies that there exist two threshold values in which the income elasticity of demand for insurance is smaller outside, but greater within the two thresholds, that is, the relationship is non-linear.

Some studies examine the relationship between economic development and the activities of the insurance market based on the data set formed by specified economic entities, such as industrialised countries ${ }^{10}$ or developing economies. ${ }^{11,12}$ Ward and Zurbruegg ${ }^{13}$ compare life insurance consumption in Asian countries and OECD countries and find that the effects of income-level as well as legal and political factors on insurance consumption are different between the two groups. The advantage of grouping countries in this way is that the biases by modelling the non-linear relationship with a linear model could be reduced since the heterogeneity among economic entities within the group is not enormous. The shortcoming is, however, that this classification method is still subjective and may not properly represent the actual property of data. ${ }^{14}$ This paper employs a threshold mechanism to endogenously divide countries into different groups based on the real income level. We also utilise the instrumental variable technique to address the potential endogeneity between economic development and the life insurance development.

As stated at the onset of the section, an issue worthwhile investigating is whether the impact of institutions on the development of life insurance varies across countries. Some studies find that institutional and political environments influence the activities of the insurance market. ${ }^{1}$ This article further

${ }^{8}$ Carter and Dickinson (1992).

${ }^{9}$ Enz (2000).

${ }^{10}$ Beenstock et al. (1986).

11 Outreville (1996); Sen (2008).

12 Outreville concentrates on the relationship between financial development and the development of the life insurance sector, but an economic development proxy is included as an explanatory variable. Sen (2008) focuses on 12 Asian economies.

13 Ward and Zurbruegg (2002).

${ }^{14}$ For instance, OECD countries are usually viewed as high-income economic entities. Based on World Development Indicators compiled by the World Bank, GDP per capita (in 2,000 US dollars) of the $25^{\text {th }}$ percentile in 27 OECD countries over 2004-2006 is around 14,615.7, $14,839.79$, and $14,889.89$ respectively. During the same period, the number of non-OECD countries with GDP per capita higher than the amount above is 13, 13, and 12 respectively. This implies that classifying data subjectively may not represent the actual contents of data as expected. 
demonstrates that the effect of institutional environments is divergent under different income regimes. We find that institutional factors, including a broad measure of civil liberties, political stability, government effectiveness, regulatory quality, rule of law, and control of corruption, have an overwhelmingly positive effect on life insurance development in low-income countries, but the effect is marginal in high-income countries. These findings indicate that the relevance of institutional environments on life insurance development is different at various stages of economic development. Our findings are robust in several alternative specifications.

This study contributes to the existing literature as follows. First, we employ a threshold regression model developed in Caner and Hansen ${ }^{15}$ to identify the non-linear relationship between life insurance development and economic development. ${ }^{16}$ Next, the threshold regression model also allows us to identify that the effects of legal and political conditions on the development of life insurance market are divergent for countries at different stages of economic development. Finally, to the best of our knowledge, this is the first article using an objectively classified technique as well as addressing the potential endogeneity issue simultaneously when investigating the relationship between life insurance development and economic development as well as other determinants. By this mechanism, we identify that important factors impacting the life insurance market do vary with the progress of economic development.

The paper proceeds as follows. The next section explains determinants of life insurance development, including demographic and socio-cultural, economic, and institutional dimensions, and why the non-linear relationship exists in the insurance market. The subsequent section then outlines the threshold regression model with an instrumental variable estimation and the testing procedure of the threshold. The latter section describes variables and data sources. Empirical results follow in the penultimate section, with summary and conclusion presented in the final section.

\section{Literature review}

This section introduces determinants of the demand for life insurance. The demand for life insurance has been shown to be affected by many different facets, including consumers' intrinsic natures, for example, risk aversion or psychographic characteristics, and external environmental influences such as economic, demographic or socio-cultural, and institutional factors. As it

\footnotetext{
${ }^{15}$ Caner and Hansen (2004).

16 The estimation and test procedures using GAUSS programming software are available from Professor Hansen's homepage.
} 
is difficult to evaluate individual consumers' internal natures such as risk aversion level or psychographic features, the discussion below focuses on quantifiable factors in demographic, economic, and institutional dimensions.

\section{Demographic or socio-cultural determinants}

Demographic or social determinants on life insurance consumption commonly used in the literature include dependency ratio, life expectancy, education level, and religion. Earlier empirical studies, focusing on the US market, show that the protection of dependants is among one of the main motives for the purchase of life insurance. ${ }^{17}$ Based on the cross-country sample, studies also demonstrate that the consumption of life insurance is significantly and positively correlated with the number of dependants or dependency ratio. ${ }^{18}$

It is generally assumed that demand for life insurance will be greater when people are expected to live longer. ${ }^{19}$ Empirical evidence finds a significantly positive relationship between life expectancy and life insurance demand. ${ }^{20}$ However, Hussels et al. ${ }^{19}$ note that it is uncertain to conclude that life expectancy leads to increased demand for insurance in the social context, because life expectancy is highly correlated with a nation's wealth and national income, such that what really matters may be greater wealth.

Education level has been argued to be related to insurance demand, because perceptions of risks increase with education. Empirical findings are, however, mixed and in some cases contradictory. Some studies suggest that education is not particularly relevant in stimulating life insurance demand. ${ }^{21}$ Browne and $\mathrm{Kim}^{22}$ even cannot achieve solid conclusions due to inconsistent results. Sen ${ }^{23}$ shows that education is a significant determinant for life insurance demand in 12 Asian economies, but the effect is negative.

Socio-cultural factors like religion or values differentiate life insurance development across countries. Zelizer ${ }^{24}$ note that religious beliefs have historically formed a source of cultural opposition to life insurance, particularly in some Muslim countries. Wasaw and Hill, ${ }^{25}$ Browne and Kim, ${ }^{22}$ Enz, ${ }^{9}$ and

${ }^{17}$ Ferber and Lee (1980); Bernheim (1991).

${ }^{18}$ Beenstock et al. (1986); Browne and Kim (1993); Beck and Webb (2003).

${ }^{19}$ Hussels et al. (2005).

${ }^{20}$ Beenstock et al. (1986); Browne and Kim (1993); Outreville (1996); Ward and Zurbruegg (2002).

${ }^{21}$ Beenstock et al. (1986); Beck and Webb (2003).

${ }^{22}$ Browne and Kim (1993).

${ }^{23}$ Sen (2008).

${ }^{24}$ Zelizer (1979).

${ }^{25}$ Wasaw and Hill (1986). 
Ward and Zurbruegg ${ }^{13}$ also confirm that life insurance consumption is less in Islamic countries. Furthermore, cultural background is related to insurance development as well. Hofstede ${ }^{26}$ points out that social values, for example, collectivism vs. individualism, influence citizens' attitude towards insurance and in turn affect insurance demand.

\section{Economic determinants}

Among economic factors affecting life insurance demand, income level should be the most fundamental factor on the purchase decision for insurance. Microbased theoretical models highlight that the demand for life insurance is positively related to anticipated or permanent income. ${ }^{27}$ Owing to the difficulty in acquiring micro-based income data, however, empirical tests have primarily utilised aggregate market and economy level data in examining the effect of income on life insurance consumption. Evidence supports a positive link between income and life insurance consumption. ${ }^{28}$

The increase in government spending on a social security system is shown to reduce the need for individuals to acquire protection via life insurance. ${ }^{29}$ Other macroeconomic factors are also empirically shown to influence life insurance demand, such as real interest rate ${ }^{30}$ and financial development. ${ }^{31}$ Zietz $^{32}$ and Hussels et al. ${ }^{19}$ provide a comprehensive review on the determinants of demand for insurance. More recently, Feyen $e t a l^{33}$ provide a newer review on factors affecting the demand for life insurance and introduce variables that are important drivers, but neglected in previous studies such as population and population density. Interested readers can refer to these articles for more detailed discussions.

The difference in some determinants above justifies the non-linear relationship of life insurance development across countries. Some studies investigate the non-linear nexus of insurance and economic development. Hammond et al. ${ }^{34}$ separate their data into low-, middle-, and high-income classes and find that life insurance premium expenditures are inelastic (0.29 and 0.66$)$ with

\footnotetext{
${ }^{26}$ Hofstede (1995).

${ }^{27}$ Yaari (1965); Hakansson (1969); Fischer (1973); Fortune (1973); Lewis (1989).

${ }^{28}$ Beenstock et al. (1986); Truett and Truett (1990); Browne and Kim (1993); Outreville (1996); Ward and Zurbruegg (2002); Beck and Webb (2003); Sen (2008); Han et al. (2010).

${ }^{29}$ Browne and Kim (1993); Beck and Webb (2003).

${ }^{30}$ Beck and Webb (2003).

${ }^{31}$ Outreville (1996).

${ }^{32}$ Zietz (2003).

${ }^{33}$ Feyen et al. (2011).

${ }^{34}$ Hammond et al. (1967).
} 
respect to income for the low- and high-income groups, and elastic (1.53) for the middle-income group. The $\mathrm{S}$-curve relation stressed by Carter and Dickinson $^{8}$ and Enz ${ }^{9}$ lends support to this viewpoint. Beenstock et al. ${ }^{10}$ specify that two reasons may cause the variation between the desired amount of insurance protection and income: (i) as income rises, more can be afforded; (ii) when the income level is higher, the dependents are likely to experience more hardship in the event of a premature death of the primary wage earner. Truett and Truett $^{35}$ show that the income elasticity of life insurance demand is higher at low-income levels than at high-income levels.

Aside from demand-led factors, a potential non-linear pattern is also characterised from the supply side in insurance markets. Higgins and Thistle ${ }^{36}$ show that insurance markets differ, because insurers are not necessarily identical and do not face identical regulatory constraints. Leng et al. ${ }^{37}$ find that regime changes characterise the interest rate series and underwriting margins. Jawadis et $a .^{38}$ note that competition between insurers and the co-existence of heterogeneous expectations from insurers who assume different and distinct costs result in asymmetrical and non-linear adjustment dynamics in insurance premiums. Linear and symmetrical assumptions on the premium adjustment dynamics are questionable due to the presence of friction in the insurance market, the heterogeneity of insurers' expectations, competition between insurers, and a strong interdependence between insurance markets.

\section{Institutions}

From the legal perspective, life insurance policies establish a long-term contractual relationship between clients and life insurance companies. That the life insurance policy tends to be a long-term contractual relationship between the insurer and the insured makes it important for life insurance companies to appropriately arrange their long-run investment plans. Long-run investment performance is of great importance for life insurers, since the match between assets and liabilities is essential for them not to default on claims payable. The protection of property rights impacts life insurers' attitude towards investment and whether they can retain investment gains. Their investment performance is then reflected in the pricing of insurance products, which in turn affects the demand for insurance. Wen and Zhang ${ }^{39}$ show that an individual's longterm investment behaviour is distorted when property rights cannot be

\footnotetext{
35 Truett and Truett (1990).

${ }^{36}$ Higgins and Thistle (2000).

${ }^{37}$ Leng et al. (2002).

38 Jawadi et al. (2009).

${ }^{39}$ Wen and Zhang (1993).
} 
assured. ${ }^{40}$ Therefore, the protection of property rights should be helpful for facilitating transactions in a life insurance market. Avram et al. ${ }^{41}$ find that the quality of the legal system and the protection of property rights exert a significant effect on the development both of life and non-life insurance sectors. Moreover, both the de jure notion of statutes on the books and the de facto execution that exists on the ground are important. Pistor et al ${ }^{42}$ indicate that the effectiveness for which the legal authority enforces the law rather than statutes on the books is what really matters for the level of financial intermediation in transition economies. Kaufmann et al. ${ }^{43}$ also argue that both formal rules and the institutional environment where these rules are applied and enforced are important.

Some new developments more recently have emerged on the discussion of institutions. The role of political risks attracts more and more attention. Roe and Siegel $^{44}$ indicate that traditionally important channels of investor protection such as legal origin, trade openness, colonial conditions, and the related and resultant institutions cannot function well under unstable political environments. Political instability impedes financial development. Ward and Zurbruegg ${ }^{13}$ show that political stability exerts a significant impact on life insurance demand both in developed and developing economies. Beck and $\mathrm{Webb}^{30}$ note that political instability affects the economic horizon of potential buyers and suppliers of life insurance products and thus may discourage the development of a healthy life insurance market. In addition, Outreville ${ }^{45}$ finds that good governance such as corruption perception and government effectiveness exerts a strong impact on the choice of countries to operate by the world finance or insurance groups.

The institutional environment in more developed countries is, generally speaking, sounder than in less developed countries. When exploring the choice of a location by the world finance and insurance groups, for instance, Outreville ${ }^{45}$ excludes OECD countries in order to avoid biases due to the perceived relationship between rich countries and good governance. It is thus reasonable to expect a better institutional environment in high-income countries. We conjecture that the effect of institutional environments on life insurance development in high-income economies is not as relevant as in low-income economies, because an

\footnotetext{
${ }^{40}$ Although Wen and Zhang (1993) analyse the effect of the Household Responsibility System, a scheme of periodical land reallocation in China, on short-term and long-term investment behaviors in China's rural areas, their notion that the protection of property rights will affect individual investment behavior is applicable to other activities within the economic system.

${ }^{41}$ Avram et al. (2010).

${ }^{42}$ Pistor et al. (2000).

${ }^{43}$ Kaufmann et al. (2005).

${ }^{44}$ Roe and Siegel (2011).

${ }^{45}$ Outreville $(2007,2008)$.
} 
increase in the quality of the institutions is less relevant if the institutions are already quite healthy.

Based on the exposition above, we construct two hypotheses to be tested as follows.

Hypothesis 1: The relationship between economic development and life insurance development is non-linear, that is there exists a significant threshold effect between economic development and life insurance development.

Hypothesis 2: Institutional environment exerts a positive impact on the development of life insurance markets, and the effect is higher in low-income countries than in high-income countries.

\section{Methodology}

\section{Model specification}

Given the considerations of the theoretical and empirical studies described above, our empirical model is structured as follows:

$$
\begin{aligned}
y_{i}= & \beta_{1} \times \mathrm{I}\left(q_{i} \leqslant \gamma\right)+\beta_{2} \text { Insti } \times \mathrm{I}\left(q_{i} \leqslant \gamma\right)+\boldsymbol{\beta}^{\prime}{ }_{3} \text { Controls } \times \mathrm{I}\left(q_{i} \leqslant \gamma\right) \\
& \beta_{4} \times \mathrm{I}\left(q_{i}>\gamma\right)+\beta_{5} \text { Insti } \times \mathrm{I}\left(q_{i}>\gamma\right)+\boldsymbol{\beta}^{\prime}{ }_{\mathbf{6}} \text { Controls } \times \mathrm{I}\left(q_{i}>\gamma\right)+\varepsilon_{i}
\end{aligned},
$$

where $y_{i}$ is the dependent variable, that is, life insurance penetration or life insurance density; Insti is the institutional variable; Controls is a set of demographic and economic determinants of life insurance demand; $q_{i}$ is the threshold variable, which is the logarithm of lagged real GDP per capita here; the threshold $\gamma \in \Gamma$ in which $\Gamma$ is a strict subset of the support of $q_{i}$ is assumed to be unknown and needs to be estimated; $I(\cdot)$ is an indicator function that is equal to one or zero depending on whether the threshold variable $q_{i}$ falls short or exceeds the unknown threshold value $\gamma ; \varepsilon_{i}$ is the error term. According to the hypotheses as constructed in the previous section, the major concern here is twofold: if the estimated $\gamma$ is significant and if $\beta_{2}>0, \beta_{5}>0$, and particularly $\beta_{2}>\beta_{5}$.

\section{Estimating the threshold and parameters}

To clarify the estimation procedure, we rewrite Equation (1) in a parsimonious form:

$$
y_{i}=\theta_{1}^{\prime} z_{i} \mathrm{I}\left(q_{i} \leqslant \gamma\right)+\theta_{2}^{\prime} z_{i} \mathrm{I}\left(q_{i}>\gamma\right)+\varepsilon_{i},
$$

where $z_{i}$ consists of institutional and control variables, and $\theta_{1}^{\prime}$ and $\theta_{2}^{\prime}$ are corresponding parameters to be estimated in Equation (1). The model allows 
the slope parameters $\theta_{1}$ and $\theta_{2}$ to switch between regimes depending on the value of $q_{i}$. Caner and Hansen ${ }^{15}$ develop the estimation and inference for linear models with endogenous variables and an exogenous threshold variable to tackle the issue of bias. In the following, we briefly present the estimation procedure, which primarily follows Caner and Hansen. ${ }^{15}$

The first step is to address the bias induced by the right-hand-side endogenous variable. The potential endogeneity of real GDP per capita, which is possibly caused by feedback from insurance development to national income or the common effect of omitted variables on both insurance development and national income, makes it infeasible to estimate the slope parameters in Equation (2) through traditional estimation methods on the threshold regressions model. Studies have documented that insurance development is positively correlated with economic development. Ward and Zurbruegg, ${ }^{46}$ for instance, show that overall insurance development and economic development have a bi-directional Granger causal relationship depending on country-specific circumstances in OECD countries. Han et l $^{47}$ further demonstrate that insurance development in developing countries, no matter in overall, life, or non-life sectors, plays a more important role in promoting economic growth than in developed economies. The potential endogeneity thus should not be neglected in this topic. In an instrumental variable threshold model, this problem can be tackled in the following sequential manner.

Estimating the following reduced form via the least squares approach:

$$
z_{i}=\pi^{\prime} x_{i}+u_{i},
$$

where $x_{i}$ consists of valid instrumental variables as well as the other exogenous control variables and needs to have a dimension larger than or equal to that of $z_{i}$, and $E\left(u_{i} \mid x_{i}\right)=0$. A commonly used instrument in the instrumental variable method is the lagged term of $z_{i}$, which is correlated with $z_{i}$, but not with $y_{i}$, so as to be viewed as exogenous to the left-hand-side variable. We thus adopt lagged GDP per capita as the instrumental variable to estimate the reducedform equation and test validity of the instrument statistically. ${ }^{48}$ After fitting the reduced-form model, we substitute the predicted values $\hat{z}_{i}=\hat{\pi}^{\prime} x_{i}$ into Equation (2) to estimate the threshold $\gamma$.

For each $\gamma$, let $Y, \hat{Z}^{-}$, and $\hat{Z}^{+}$represent the matrices of stacked vectors $y_{i}$, ${\hat{z^{\prime}}}_{i} \mathrm{I}\left(q_{i} \leqslant \gamma\right)$, and ${\hat{z^{\prime}}}_{i} \mathrm{I}\left(q_{i}>\gamma\right)$, respectively. The LS residual sum of squared errors can be obtained via regressing $Y$ on $\hat{Z}^{-}$and $\hat{Z}^{+}$. Here, $\gamma$ with minimum sum of

\footnotetext{
${ }^{46}$ Ward and Zurbruegg (2000).

${ }^{47}$ Han et al. (2010).

${ }^{48}$ Zheng et al. (2009) also use one-period lagged GDP per capita to deal with the potential endogeneity problem in the robustness check.
} 
squared errors is the 2SLS estimator of the threshold. The slope parameters $\theta_{1}$ and $\theta_{2}$ can then be estimated by performing two-stage least-squares (2SLS) or generalised method of moments (GMM) methods separately on each subsample split by the estimate $\hat{\gamma}$. Interested readers are referred to Caner and Hansen's ${ }^{15}$ paper for detailed derivations.

\section{Testing for the threshold effect}

In Equation (2) the threshold effect disappears if $\theta_{1}$ does not differ significantly from $\theta_{2}$. It is thus necessary to test whether the threshold effect really exists, that is, testing the hypothesis:

$$
H_{0}: \theta_{1}=\theta_{2}
$$

The test statistic is formed as follows. First, for any fixed threshold value $\gamma \in \Gamma$, estimate $\theta_{1}$ and $\theta_{2}$ in Equation (2) by GMM. With the corresponding estimated covariance matrices $\hat{V}_{1}(\gamma)$ and $\hat{V}_{2}(\gamma)$, next construct the Wald statistic for $H_{0}$ as:

$$
W_{n}(\gamma)=\left(\hat{\theta}_{1}(\gamma)-\hat{\theta}_{2}(\gamma)\right)^{\prime}\left(\hat{V}_{1}(\gamma)+\hat{V}_{2}(\gamma)\right)^{-1}\left(\hat{\theta}_{1}(\gamma)-\hat{\theta}_{2}(\gamma)\right)
$$

The calculation is repeated for all $\gamma \in \Gamma$, and then the largest value of these statistics is denoted as the Sup statistic:

$$
\operatorname{Sup} W=\sup _{\gamma \in \Gamma} W_{n}(\gamma)
$$

The asymptotic distribution of this test statistic is not chi-square, because the parameter $\gamma$ is not identified under the null hypothesis. Nevertheless, its asymptotic distribution can be written as the supremum of a chi-square process and can be calculated by the simulation documented by Hansen. ${ }^{49}$ Define the pseudo-dependent variable $y_{i}^{*}=\hat{e}_{i}(\gamma) \eta_{i}$, where $\hat{e}_{i}(\gamma)$ represents the residual estimated from the unrestricted model for each $\gamma$, and $\eta_{i}$ is a random draw from independent and identically distributed $N(0,1)$. Replacing $y_{i}$ with the pseudodependent variable and repeating the calculation presented above, we now obtain the statistic Sup $W^{*}$ with the same asymptotic distribution as Sup $W$.

${ }^{49}$ Hansen (1996). 


\section{Variables and data}

\section{The measures of economic development and life insurance development}

We use real GDP per capita to measure the level of economic development. Lagged real GDP per capita is used as the instrumental variable to address potential endogeneity and is also the threshold variable.

In the existing literature, the two commonly used indicators of insurance activities, that is, insurance penetration and insurance density, are individually not a perfect measure for the association of insurance activities with economic activities. ${ }^{50}$ Insurance penetration, defined as the ratio of insurance premium to GDP, associates the scale of the insurance market with that of the economy, but ignores the population factor. Insurance density, defined as the premium per capita, on the other hand, takes population into consideration, but neglects economic development. Zheng et al. ${ }^{50}$ indicate that an alternative form, insurance density/GDP per capita by means of adjusting insurance penetration via dividing the numerator and denominator by population, could mitigate the defect by incorporating economic factors into the insurance density. However, they argue that this adjustment fails to reflect the fact that insurance penetration is different at various stages of economic development.

In this article we employ both insurance penetration and insurance density in the empirical analysis so that the deficiency of using individual indicators could be alleviated. Moreover, the threshold technique we utilise addresses the issue that insurance development is divergent along with economic development.

\section{Institutional variables}

This paper adopts the worldwide governance indicators (WGI) updated by Kaufmann et al. ${ }^{51}$ to investigate the effect of institutional environment on the life insurance market. Kaufmann et al.'s WGI is a perceptions-based measure about how a diverse range of individuals within a country, including households, firms, and experts working for private sector and public sector agencies, perceives institutional circumstances in their country. The six indicators are voice and accountability, political stability and absence of violence, government effectiveness, regulatory quality, rule of law, and control of corruption. A higher score represents a sounder institutional environment. ${ }^{52}$ Since Kaufmann et al.'s six governance indicators can be associated with legal and political circumstances

\footnotetext{
50 Zheng et al. (2009).

${ }^{51}$ Kaufmann et al. (2009).

52 Interested readers are referred to their paper for more details.
} 
within a country, we average the six indicators into the overall measure of institutional environment.

We utilize Kaufmann et al.'s ${ }^{51}$ perceptions-based measure of governance for two reasons. First and most important, perceptions do matter, because individuals usually base their decisions on their perceptions, impression, and views. The purchase of insurance is among one of an individual's many decisions, and thus individuals' perceptions regarding the healthiness of the institutional environment in their country may affect their decision to purchase insurance. For instance, if citizens think that their rights when being a party to a contract cannot be properly protected due to unsound legal rules or inefficient courts, then their willingness to enter into an insurance contract may be diminished.

Second, some institutional variables such as political stability and corruption are qualitative and difficult to be measured. An accepted technique that addresses this issue is to develop the metric by aggregating multiple sources. ${ }^{53}$ Kaufmann et al.'s ${ }^{51}$ WGI is an aggregated measure compiled from several sources in an econometrically consistent method and is comparable across countries and over time. This enables WGI to avoid possible weakness of another oft-used indicator, for example, International Country Risk Guide (ICRG) prepared by the PRS Group, which, although compiled in an extremely rigorous manner, consists of a single source. ${ }^{54,55}$

\section{Control variables}

We select determinants of life insurance demand on the basis of the existant literature as noted in the second section, subject to data availability and the requirement for including as many observations as possible. We adopt three demographic elements: young dependency ratio (ratio of younger dependents to the working-age population), old dependency ratio (ratio of older dependents to the working-age population), and life expectancy at birth. We divide the dependency ratio into young and old dependency, because life insurance

${ }^{53}$ UNDP (2008).

${ }^{54}$ Bonini and Alkan Aktuccar (2009).

${ }^{55}$ Although Kaufmann et al.'s governance indicators have specific advantages, some reminders should be addressed. The governance indicators are not the only important institutional factors related to the development of insurance markets. Other dimensions of institutional environments are important as well and have been studied in the literature, for example, market structure (Outreville 1991) and political stability and human capital (Outreville, 1999). Different measures will generate individual-specific implications for insurance development across countries. The intention in this article is to complement the existant literature by utilising alternative indicators with some specific characteristics. 
products provide indemnity for two risks: mortality and longevity risk. Moreover, some insurance products are also equipped with a savings characteristic. Different age groups demand different types of indemnities, resulting in the divergent effect of demographic elements on life insurance development.

We include four economic determinants: income, inflation, social security expenditure, and real interest rate. The effect of income on life insurance consumption is introduced above. Inflation is expected to adversely affect life insurance development, because life insurance products provide monetary benefits over the long term, but inflation erodes the cash value received in the future. The government expenditure on social security and welfare is expected to negatively correlate with the demand for life insurance products. We employ public health expenditure as a share of GDP to measure the size of the social security system. The interest rate has an ambiguous effect on life insurance consumption. On the one hand, a higher interest rate reduces the life insurance premium, stimulating demand for life insurance products. On the other hand, a higher interest rate implies a higher return on alternative investment vehicles, inducing individuals to shift funds to other investment instruments. Appendix B summarises the definitions and data sources of the variables used in this study.

\section{Data}

The data used in this study consists of 92 countries, with real GDP per capita (in 2,000 US dollars), ranging from US $\$ 367.48$ to US $\$ 48,485.34$ over the period 1996-2008. We obtain the data on life insurance development from Financial Structure Dataset updated by Beck and Demirgüç-Kunt ${ }^{56}$ and on the institutional environment from the WGI constructed by Kaufmann et al. ${ }^{51,57}$ The data for real GDP per capita and conditioning information sets is extracted from World Development Indicators ${ }^{58}$ compiled by the World Bank.

Kaufmann et al.'s ${ }^{51}$ WGI indicators cover the period 1996-2008 with gaps in 1997, 1999, and 2001, reducing the investigation period from 13 years to 10 years. The sample includes 716 observations due to missing information and the exclusion of some extreme outliers when we incorporate the demographic information set. Moreover, the data for public health expenditure in the WDI database covers an even shorter period 2002-2006. This further reduces our sample to 296 observations comprised by 75 countries after we control for the economic determinants.

\footnotetext{
${ }^{56}$ Beck and Demirgüç-Kunt (2009).

${ }^{57}$ Insurance premium data in Beck and Demirgüç-Kunt's data set is taken from various issues of Sigma reports (Swiss Re).

${ }^{58}$ WDI (2010).
} 


\section{Empirical results}

\section{Preliminary analysis}

Table 1 presents the descriptive statistics of the full samples and of key variables for different income groups. ${ }^{59}$ As can be seen in Panel B, the level of life insurance development is higher in high-income countries. Moreover, as expected, institutional environment is healthier in high-income economies, which is reflected on a higher score in all institutional indicators.

To preliminarily detect the existence of non-linearity, we adopt the kernel regression to portray the relationship between the level of economic development and life insurance activities. The kernel regression is a commonly used non-parametric method to analyse non-linear models. Since the non-linear function in the kernel regression is estimated from the data, it is highly datadependent. ${ }^{60}$ The data-dependent feature allows us to check the characteristic of the actual data so that any suspicion about associations fitted with sophisticated econometrics can be alleviated.

Figure 1 plots the relationship between real GDP per capita and life insurance penetration. The relation does present a non-linear pattern as life insurance activities start to grow quickly after income achieves some certain level. The pattern of non-linearity is replicated with life insurance density. As Figure 2 shows, the relationship between real GDP per capita and life insurance density reveals an S-curve shape, which corresponds to Carter and Dickinson's ${ }^{8}$ and Enz's ${ }^{9}$ arguments. The visual inspection of actual data reveals the non-linear relationship between economic development and life insurance development, which is further examined with a rigorous econometric method in the following.

\section{Instrumental variable threshold regression results}

In this subsection we perform the threshold regressions to characterize the nonlinearity between economic development and activities of the life insurance market. ${ }^{61}$ We use the lagged real GDP per capita for each country as the

\footnotetext{
59 The two groups in panel B are distinguished by using life insurance penetration as the measure of life insurance development. The statistics based on life insurance density are qualitatively the same and not reported to save space.

60 Tsay (2005).

${ }^{61} \mathrm{We}$ also run linear regression analysis to examine the overall effects from income level and institutional environments. Both the income level and institution variable are significantly and positively correlated with the two measures of the life insurance market. To roughly examine the non-linear relationship between real income level and life insurance development, we also include the square term of the logarithm of GDP per capita as an additional regressor.
} 
Table 1 Descriptive statistics

\begin{tabular}{|c|c|c|c|}
\hline & Observations & Mean & Std. dev. \\
\hline \multicolumn{4}{|c|}{ Panel A: Full samples } \\
\hline Penetration & 716 & 2.66 & 3.43 \\
\hline Density & 716 & 4.49 & 2.39 \\
\hline Pcgdp & 716 & 8.73 & 1.26 \\
\hline Institution & 716 & 0.52 & 0.85 \\
\hline Dep_old & 716 & 15.19 & 7.50 \\
\hline Dep_young & 716 & 38.12 & 15.58 \\
\hline Life_exp & 716 & 73.74 & 6.25 \\
\hline Health & 296 & 4.18 & 2.15 \\
\hline Inflation & 296 & 4.86 & 5.38 \\
\hline Interest & 296 & 4.43 & 5.05 \\
\hline VA & 296 & 0.49 & 0.84 \\
\hline PV & 296 & 0.19 & 0.92 \\
\hline GE & 296 & 0.63 & 0.93 \\
\hline RQ & 296 & 0.58 & 0.82 \\
\hline $\mathrm{RL}$ & 296 & 0.45 & 0.94 \\
\hline $\mathrm{CC}$ & 296 & 0.48 & 1.02 \\
\hline \multicolumn{4}{|c|}{ Panel B: Different income groups } \\
\hline \multicolumn{4}{|c|}{ High-income group } \\
\hline Penetration & 113 & 4.50 & 2.83 \\
\hline Pcgdp & 113 & 9.97 & 0.44 \\
\hline Institution & 113 & 1.27 & 0.51 \\
\hline VA & 109 & 1.15 & 0.56 \\
\hline PV & 109 & 0.86 & 0.66 \\
\hline GE & 113 & 1.54 & 0.61 \\
\hline RQ & 113 & 1.29 & 0.47 \\
\hline RL & 109 & 1.42 & 0.46 \\
\hline $\mathrm{CC}$ & 110 & 1.53 & 0.64 \\
\hline \multicolumn{4}{|c|}{ Low-income group } \\
\hline Penetration & 183 & 1.40 & 2.20 \\
\hline Pcgdp & 183 & 7.78 & 0.81 \\
\hline Institution & 183 & -0.03 & 0.61 \\
\hline VA & 187 & 0.11 & 0.73 \\
\hline PV & 187 & -0.21 & 0.81 \\
\hline GE & 183 & 0.07 & 0.58 \\
\hline RQ & 183 & 0.14 & 0.66 \\
\hline $\mathrm{RL}$ & 187 & -0.12 & 0.62 \\
\hline $\mathrm{CC}$ & 186 & -0.14 & 0.60 \\
\hline
\end{tabular}

Coefficients on both the income level and its square term are significant, and the negative coefficient on income level along with the positive coefficient on its square term implies that an increase in income promotes life insurance activities after attaining some income threshold. These results are not reported to save space, but available from the authors upon request. 


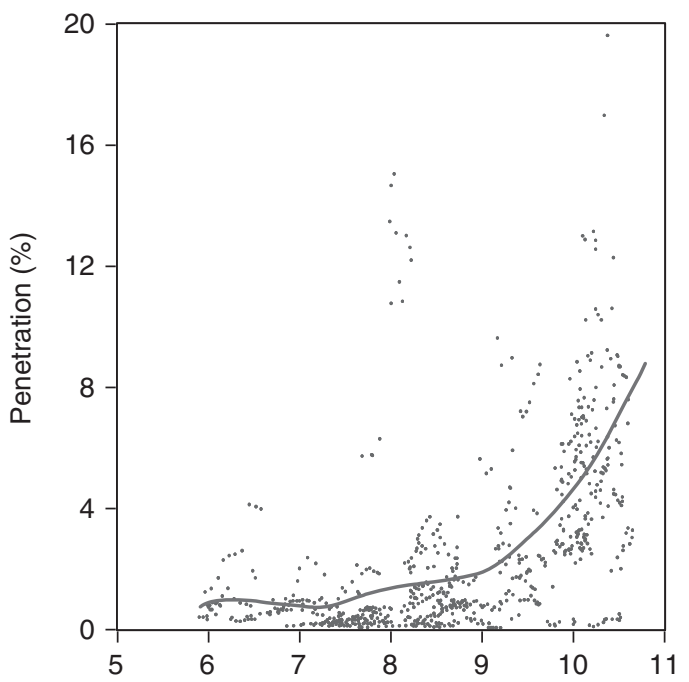

Figure 1. Kernel regression fit-life insurance penetration and economic development. The horizontal axis is real GDP per capita in natural logarithm, and the vertical axis is life insurance penetration.

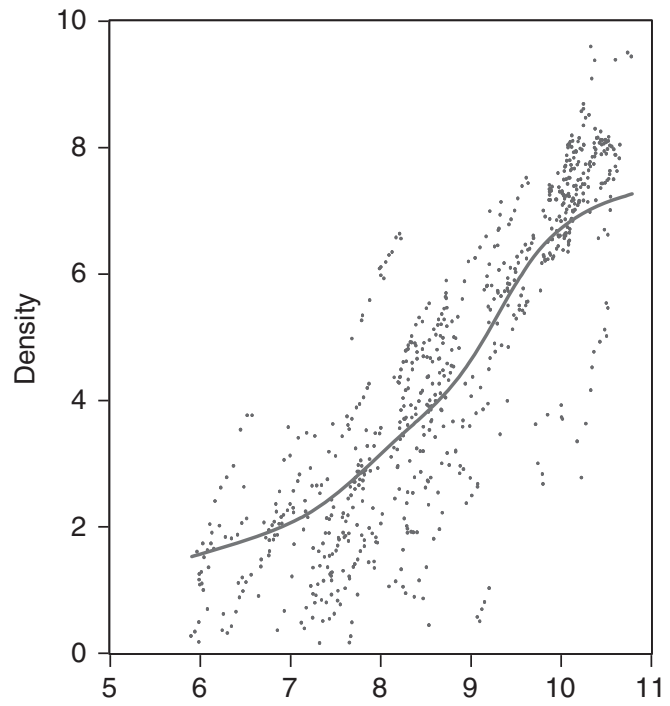

Figure 2. Kernel regression fit-life insurance density and economic development. The horizontal axis is real GDP per capita in natural logarithm, and the vertical axis is life insurance density in natural logarithm. 
threshold variable as well as the instrument because it can measure the level of one country's economic development and avoid the reverse causation of contemporaneous life insurance premium, i.e., the endogeneity issue. Tables 2 and 3 report the Sup $W$ test of income threshold as well as the parameters of primary interest for life insurance penetration and density, respectively. As shown in the upper-panel of Tables 2 and 3, the Sup $W$ test statistics indicate that there is a highly significant threshold effect of real income. The results hold for alternative measures of life insurance development and the inclusion of different controlling information sets. Our first hypothesis is thus verified. We split the sample into two regimes based on the estimated $\hat{\gamma}$ and refer to economic entities with real GDP per capita less than $\hat{\gamma}$ as low-income countries and those with real GDP per capita more than $\hat{\gamma}$ as high-income countries.

We recover the estimated income threshold in the logarithm form to the level term. The income level ranges from 7,288.48 $(\hat{\gamma}=8.894)$ to $13,844.53(\hat{\gamma}=$ 9.536) for penetration and from 7,229.48 $(\hat{\gamma}=8.886)$ to $9,965.88(\hat{\gamma}=9.207)$ for density with the inclusion of different sets of control variables. Two observations are noted. First, $\mathrm{Enz}^{9}$ observes that the income elasticity of demand for life insurance significantly increases after real GDP per capita of US $\$ 1,000$ and reaches the highest level at US\$15,000 (see Figure 4 in Enz's paper). Our estimated income thresholds fall within this range and locate in the rising stage of income elasticity of the demand for life insurance. ${ }^{62}$ Second, the income threshold decreases when more control variables are included. This suggests that the consideration of income on the purchase decision of life insurance diminishes when other determinants are taken into account, for example, life expectancy and dependants.

Table 2 shows that the real income level is significantly and positively correlated with life insurance penetration for both income regimes at a high significance level of 1 per cent except for the model (1). The effect of an income increase on life insurance penetration is higher for high-income countries, and the results are robust to alternative sets of controlling variables. The findings based on life insurance penetration are replicated with life insurance density, as seen in Table 3. Because insurance density and income are taken in the logarithmic form, the estimated parameter of income is a measure of elasticity. The income elasticity of demand for life insurance is less than or approximately one under different model specifications in the low-income regime, but is larger than 1 for all specifications in the high-income regime.

\footnotetext{
${ }^{62}$ Our results are not directly comparable with those of Enz (2000), because the sample countries included and the period are different and Enz only consider the income level. However, our results support his observation to some extent.
} 
Table 2 Threshold regression with instrumental variable results - life insurance penetration

\begin{tabular}{|c|c|c|c|c|c|c|}
\hline \multirow{5}{*}{$\begin{array}{l}\hat{\gamma} \\
\text { C.I. } \\
\text { Sup W }\end{array}$} & \multicolumn{2}{|c|}{ (1) } & \multicolumn{2}{|c|}{ (2) } & \multicolumn{2}{|c|}{ (3) } \\
\hline & \multirow{3}{*}{\multicolumn{2}{|c|}{$\begin{array}{c}9.536 \\
{[7.938,9.727]} \\
93.651 * * *\end{array}$}} & \multirow{3}{*}{\multicolumn{2}{|c|}{$\begin{array}{c}9.302 \\
{[7.958,9.684]} \\
341.600 * * *\end{array}$}} & \multirow{3}{*}{\multicolumn{2}{|c|}{$\begin{array}{c}8.894 \\
{[8.886,9.343]} \\
328.156^{* * *}\end{array}$}} \\
\hline & & & & & & \\
\hline & & & & & & \\
\hline & $p c g d p 0 \leqslant \gamma$ & $p c g d p 0>\gamma$ & $p c g d p 0 \leqslant \gamma$ & $p c g d p 0>\gamma$ & $p c g d p 0 \leqslant \gamma$ & $p \operatorname{cgd} 00>\gamma$ \\
\hline \multirow[t]{2}{*}{ Pcgdp } & -0.030 & $5.044 * * *$ & $0.672 * * *$ & $4.431 * * *$ & $1.007 * * *$ & $3.211^{* * *}$ \\
\hline & $(0.106)$ & (1.295) & $(0.149)$ & (1.024) & $(0.245)$ & $(0.475)$ \\
\hline \multirow[t]{2}{*}{ Institution } & $1.134 * * *$ & 0.699 & $1.425^{* * *}$ & 0.241 & $1.013 * * *$ & 0.337 \\
\hline & $(0.136)$ & $(0.421)$ & $(0.146)$ & $(0.404)$ & $(0.212)$ & $(0.470)$ \\
\hline \multirow[t]{2}{*}{ Dep_old } & & & $-0.213^{* * *}$ & 0.009 & $-0.196^{* * *}$ & $0.288^{* * *}$ \\
\hline & & & $(0.024)$ & $(0.041)$ & $(0.035)$ & $(0.077)$ \\
\hline \multirow[t]{2}{*}{ Dep_young } & & & $-0.069 * * *$ & $-0.128 * * *$ & $-0.060 * * *$ & -0.041 \\
\hline & & & $(0.009)$ & $(0.035)$ & $(0.013)$ & $(0.039)$ \\
\hline \multirow[t]{2}{*}{ Life_exp } & & & $-0.252 * * *$ & -0.241 & $-0.232 * * *$ & $-0.504 * * *$ \\
\hline & & & (0.039) & $(0.197)$ & $(0.050)$ & $(0.103)$ \\
\hline \multirow[t]{2}{*}{ Health } & & & & & $-0.211 * * *$ & $-0.793 * * *$ \\
\hline & & & & & $(0.074)$ & $(0.166)$ \\
\hline \multirow[t]{2}{*}{ Inflation } & & & & & $-0.043^{* * *}$ & $-0.269 * * *$ \\
\hline & & & & & $(0.016)$ & $(0.084)$ \\
\hline \multirow[t]{2}{*}{ Interest } & & & & & -0.014 & -0.109 \\
\hline & & & & & $(0.016)$ & $(0.082)$ \\
\hline \multirow[t]{2}{*}{ Constant } & $1.563^{*}$ & $-47.010 * * *$ & $19.303 * * *$ & -17.589 & $15.841 * * *$ & $12.916 * *$ \\
\hline & $(0.850)$ & $(12.890)$ & $(2.474)$ & (10.836) & (3.117) & $(6.460)$ \\
\hline Observations & 480 & 236 & 446 & 270 & 183 & 113 \\
\hline $\operatorname{Adj} R^{2}$ & \multicolumn{2}{|c|}{0.359} & \multicolumn{2}{|c|}{0.471} & \multicolumn{2}{|c|}{0.634} \\
\hline First-stage test: $p$-value & 0.000 & 0.000 & 0.000 & 0.000 & 0.000 & 0.000 \\
\hline
\end{tabular}

***Significant at the 1 per cent level; **Significant at the 5 per cent level; *Significant at the 10 per cent level.

Notes: Standard errors in parentheses. $\hat{\gamma}$ is the estimated threshold value, C.I. is the confidence interval corresponding to the estimated threshold value, and Sup $W$ is the largest value of a series of the Wald statistics estimated under different threshold values. The dependent variable is life insurance penetration. Pcgdp is the natural logarithm of real GDP per capita. Institution is the average of six indicators measuring voice and accountability, political stability, government effectiveness, regulatory quality, rule of law, and control of corruption. See Appendix B for definitions of other control variables. The lagged Pcgdp is used as an instrumental variable and a threshold variable. The null hypothesis for the first-stage test is that the coefficient on the instrument is zero.

At first glance, our findings concerning the effect of real income on life insurance development seem at odds with Ward and Zurbruegg's ${ }^{13}$ findings, which indicate that the estimated income effect on life insurance development is higher for developing economies in Asia than for the more developed OECD countries. This does not mean, however, that our results contrast with Ward and Zurbruegg's 
Table 3 Threshold regression with instrumental variable results - life insurance density

\begin{tabular}{|c|c|c|c|c|c|c|}
\hline \multirow{5}{*}{$\begin{array}{l}\hat{\gamma} \\
\text { C.I. } \\
\text { Sup W }\end{array}$} & \multicolumn{2}{|c|}{ (1) } & \multicolumn{2}{|c|}{ (2) } & \multicolumn{2}{|c|}{ (3) } \\
\hline & \multirow{3}{*}{\multicolumn{2}{|c|}{$\begin{array}{c}9.207 \\
{[9.102,9.343]} \\
42.466^{* * *}\end{array}$}} & \multirow{3}{*}{\multicolumn{2}{|c|}{$\begin{array}{c}8.886 \\
{[8.474,9.076]} \\
266.213^{* * *}\end{array}$}} & \multirow{3}{*}{\multicolumn{2}{|c|}{$\begin{array}{c}8.886 \\
{[8.844,9.085]} \\
130.153^{* * *}\end{array}$}} \\
\hline & & & & & & \\
\hline & & & & & & \\
\hline & $p \operatorname{cgd} d p \leqslant \gamma$ & $p c g d p 0>\gamma$ & $p c g d p 0 \leqslant \gamma$ & $p c g d p 0>\gamma$ & $p c g d p 0 \leqslant \gamma$ & $p \operatorname{cgd} 00>\gamma$ \\
\hline \multirow[t]{2}{*}{ Pcgdp } & $0.538 * * *$ & $1.258 * * *$ & $0.911 * * *$ & $1.300 * * *$ & $0.988 * * *$ & $1.601 * * *$ \\
\hline & $(0.083)$ & $(0.195)$ & $(0.086)$ & $(0.180)$ & (0.119) & $(0.198)$ \\
\hline \multirow[t]{2}{*}{ Institution } & $1.372 * * *$ & $0.728 * * *$ & $1.264 * * *$ & $0.572 * * *$ & $1.080 * * *$ & $0.443^{* *}$ \\
\hline & $(0.119)$ & $(0.235)$ & $(0.124)$ & $(0.140)$ & $(0.164)$ & $(0.206)$ \\
\hline \multirow[t]{2}{*}{ Dep_old } & & & $-0.097 * * *$ & $0.040 * * *$ & $-0.097 * * *$ & $0.132 * * *$ \\
\hline & & & $(0.013)$ & $(0.014)$ & $(0.020)$ & $(0.034)$ \\
\hline \multirow[t]{2}{*}{ Dep_young } & & & $-0.037 * * *$ & $-0.055^{* * *}$ & $-0.036^{* * *}$ & -0.025 \\
\hline & & & $(0.004)$ & $(0.013)$ & $(0.006)$ & $(0.020)$ \\
\hline \multirow[t]{2}{*}{ Life_exp } & & & $-0.089 * * *$ & 0.001 & $-0.081 * * *$ & $-0.155^{* * *}$ \\
\hline & & & $(0.011)$ & $(0.045)$ & $(0.012)$ & $(0.049)$ \\
\hline \multirow[t]{2}{*}{ Health } & & & & & -0.076 & $-0.296 * * *$ \\
\hline & & & & & $(0.058)$ & $(0.062)$ \\
\hline \multirow[t]{2}{*}{ Inflation } & & & & & $-0.058 * * *$ & $-0.062^{*}$ \\
\hline & & & & & $(0.014)$ & $(0.032)$ \\
\hline \multirow[t]{2}{*}{ Interest } & & & & & -0.011 & -0.029 \\
\hline & & & & & $(0.011)$ & $(0.031)$ \\
\hline \multirow[t]{2}{*}{ Constant } & $-1.263^{*}$ & $-6.726 * * *$ & $4.898 * * *$ & $-6.344 * *$ & $4.438 * * *$ & 2.534 \\
\hline & $(0.650)$ & $(1.755)$ & $(0.849)$ & (3.159) & (1.033) & $(3.777)$ \\
\hline Observations & 435 & 281 & 402 & 314 & 182 & 114 \\
\hline $\operatorname{Adj} R^{2}$ & \multicolumn{2}{|c|}{0.808} & \multicolumn{2}{|c|}{0.854} & \multicolumn{2}{|c|}{0.886} \\
\hline First-stage test: $p$-value & 0.000 & 0.000 & 0.000 & 0.000 & 0.000 & 0.000 \\
\hline
\end{tabular}

***Significant at the 1 per cent level; **Significant at the 5 per cent level; ${ }^{*}$ Significant at the 10 per cent level.

Notes: Robust standard errors in parentheses. $\hat{\gamma}$ is the estimated threshold value, C.I. is the confidence interval corresponding to the estimated threshold value, and Sup $W$ is the largest value of a series of the Wald statistics estimated under different threshold values. The dependent variable is life insurance density in the natural logarithm form. Pcgdp is the natural logarithm of real GDP per capita. Institution is the average of six indicators measuring voice and accountability, political stability, government effectiveness, regulatory quality, rule of law, and control of corruption. See Appendix B for definitions of other control variables. The lagged Pcgdp is used as an instrumental variable and a threshold variable. The null hypothesis for the first-stage test is that the coefficient on the instrument is zero.

findings. Rather, it could be interpreted that our findings here portray the formerhalf segment of the S-curve, while Ward and Zurbruegg characterise the latter-half one. The S-curve shape implies that there should exist two thresholds for the effect of income changes on life insurance development. In a robustness check later, we will further verify the S-curve pattern by a double threshold model. 
Our other variable of interest, institutional environment, also has a divergent effect on life insurance development for different income regimes. The institutional variable is significantly and positively correlated with life insurance penetration for low-income countries at the significance level of 1 per cent while the effect is not significant for high-income countries. The results of life insurance density are somewhat different, whereby the institutional variable has a statistically significant influence for both regimes. However, the influence is more important for low-income countries since the magnitude in coefficient estimates is larger. Our second hypothesis is supported as well.

The impact of demographic and economic factors on life insurance activities is also different depending on the level of economic development. As stated in the previous section, the effects from the three demographic factors are ambiguous due to the complicated feature of life insurance products. The results show that all three factors are significantly and negatively correlated with life insurance development in low-income countries. The demographic results are mixed for high-income countries. As expected, government expenditure on social welfare and inflation are in general negatively correlated with life insurance activities in both income regimes.

\section{The relevance of specific governance indicators}

This subsection further evaluates the impact of specific governance indicators. The governance indicators developed by Kaufmann et al. ${ }^{51}$ are associated with legal and political dimensions within a country. We classify the six governance indicators into two aspects based on their definition. Regulatory quality (RQ) and rule of law (RL) are correlated with the legal circumstance, and government effectiveness (GE), voice and accountability (VA), political stability and absence of violence (PV), and control of corruption (CC) are correlated with the political circumstance. The results are provided in Tables 4 and 5 .

For brevity, we report only the coefficients on the real income variable and governance indicators. ${ }^{63}$ As shown in Tables 4 and 5, all six governance indicators exert a statistically positive impact on life insurance activities in low-income

${ }^{63}$ We regress the six institutional variables jointly and find mixed results, that is, some variables have a positive coefficient and some negative. This should be expected as these variables cover legal and political dimensions within an economy and interactive influence among these variables may exist. The potential interaction or trade-off effect obscures the influence of certain variables and it is difficult to give a meaningful interpretation. The six indicators are highly correlated, as the minimum correlation coefficient among them is 0.722 . Outreville (2008) uses only one variable at a time when evaluating the effect of governance on insurance groups' choice of a location as variables used to measure governance are highly correlated. The results are thus not reported, but available on request. 
Table 4 The effect of specific institutional factors - life insurance penetration

\begin{tabular}{|c|c|c|c|c|c|c|}
\hline \multirow{3}{*}{$\begin{array}{l}\hat{\gamma} \\
\text { C.I. } \\
\text { Sup W }\end{array}$} & \multicolumn{2}{|c|}{$R Q$} & \multicolumn{2}{|c|}{$R L$} & \multicolumn{2}{|c|}{$G E$} \\
\hline & \multicolumn{2}{|c|}{$\begin{array}{c}8.894 \\
{[8.886,9.076]} \\
308.955^{* * *}\end{array}$} & \multicolumn{2}{|c|}{$\begin{array}{c}9.057 \\
{[8.886,9.343]} \\
325.742 * * *\end{array}$} & \multicolumn{2}{|c|}{$\begin{array}{c}8.894 \\
{[8.886,9.057]} \\
300.204 * * *\end{array}$} \\
\hline & $\operatorname{pcgdp} 0 \leqslant \hat{\gamma}$ & $\operatorname{pcgdp} 0>\hat{\gamma}$ & $\operatorname{pcgdp} 0 \leqslant \hat{\gamma}$ & $\operatorname{pcgdp} 0>\hat{\gamma}$ & $\operatorname{pcgdp} 0 \leqslant \hat{\gamma}$ & $\operatorname{pcgdp} 0>\hat{\gamma}$ \\
\hline Pcgdp & $\begin{array}{l}1.176^{* * *} \\
(0.251)\end{array}$ & $\begin{array}{l}2.963 * * * \\
(0.472)\end{array}$ & $\begin{array}{l}1.291 * * * \\
(0.229)\end{array}$ & $\begin{array}{l}3.077 * * * \\
(0.534)\end{array}$ & $\begin{array}{l}0.800^{* * * *} \\
(0.214)\end{array}$ & $\begin{array}{l}2.976^{* * *} \\
(0.547)\end{array}$ \\
\hline RQ & $\begin{array}{l}0.671 * * * \\
(0.190)\end{array}$ & $\begin{array}{c}0.750 \\
(0.551)\end{array}$ & & & & \\
\hline RL & & & $\begin{array}{l}0.545^{* * *} \\
(0.168)\end{array}$ & $\begin{array}{c}0.444 \\
(0.538)\end{array}$ & & \\
\hline GE & & & & & $\begin{array}{l}1.508^{* * *} \\
(0.227)\end{array}$ & $\begin{array}{c}0.471 \\
(0.346)\end{array}$ \\
\hline $\begin{array}{l}\text { Observations } \\
\text { Adj } R^{2}\end{array}$ & \multicolumn{2}{|c|}{$\begin{array}{ll}183 & 0.632\end{array}$} & \multicolumn{2}{|c|}{0.629} & \multicolumn{2}{|c|}{0.646} \\
\hline First-stage test: $p$-value & 0.000 & 0.000 & 0.000 & 0.000 & 0.000 & 0.000 \\
\hline \multirow{3}{*}{$\begin{array}{l}\hat{\gamma} \\
\text { C.I. } \\
\text { Sup W }\end{array}$} & \multicolumn{2}{|c|}{$V A$} & \multicolumn{2}{|c|}{$P V$} & \multicolumn{2}{|c|}{$C C$} \\
\hline & \multicolumn{2}{|c|}{$\begin{array}{c}9.057 \\
{[8.886,9.343]} \\
357.433^{* * *}\end{array}$} & \multicolumn{2}{|c|}{$\begin{array}{c}9.057 \\
{[8.886,9.343]} \\
374.906^{* * *}\end{array}$} & \multicolumn{2}{|c|}{$\begin{array}{c}8.999 \\
{[8.886,9.343]} \\
342.250 * * *\end{array}$} \\
\hline & $\operatorname{pcgdp} 0 \leqslant \hat{\gamma}$ & $\operatorname{pcgdp} 0>\hat{\gamma}$ & $\operatorname{pcgdp} 0 \leqslant \hat{\gamma}$ & $\operatorname{pcgdp} 0>\hat{\gamma}$ & $\operatorname{pcgdp} 0 \leqslant \hat{\gamma}$ & $\operatorname{pcgdp} 0>\hat{\gamma}$ \\
\hline Pcgdp & $\begin{array}{l}1.110^{* * *} \\
(0.218)\end{array}$ & $\begin{array}{l}3.327 * * * \\
(0.515)\end{array}$ & $\begin{array}{l}1.251^{* * *} \\
(0.239)\end{array}$ & $\begin{array}{l}3.359^{* * *} \\
(0.523)\end{array}$ & $\begin{array}{l}1.123^{* * *} \\
(0.214)\end{array}$ & $\begin{array}{l}3.533^{* * *} \\
(0.551)\end{array}$ \\
\hline VA & $\begin{array}{l}0.611 * * * \\
(0.169)\end{array}$ & $\begin{array}{l}1.120 * * \\
(0.550)\end{array}$ & & & & \\
\hline PV & & & $\begin{array}{l}0.422 * * \\
(0.176)\end{array}$ & $\begin{array}{c}-0.220 \\
(0.306)\end{array}$ & & \\
\hline $\mathrm{CC}$ & & & & & $\begin{array}{l}0.791 * * * \\
(0.236)\end{array}$ & $\begin{array}{c}-0.216 \\
(0.394)\end{array}$ \\
\hline Observations & 187 & 109 & 187 & 109 & 186 & 110 \\
\hline Adj $R^{2}$ & \multicolumn{2}{|c|}{0.636} & \multicolumn{2}{|c|}{0.628} & \multicolumn{2}{|c|}{0.631} \\
\hline First-stage test: $p$-value & 0.000 & 0.000 & 0.000 & 0.000 & 0.000 & 0.000 \\
\hline
\end{tabular}

***Significant at the 1 per cent level; **Significant at the 5 per cent level; $*$ Significant at the 10 per cent level.

Notes: Standard errors in parentheses. $\hat{\gamma}$ is the estimated threshold value, C.I. is the confidence interval corresponding to the estimated threshold value, and Sup $W$ is the largest value of a series of the Wald statistics estimated under different threshold values. The dependent variable is insurance penetration. Pcgdp is the natural logarithm of real GDP per capita. RQ is regulatory quality. RL is rule of law. GE is government effectiveness. VA is Voice and accountability. PV is political stability and absence of violence. CC is control of corruption. Controlling variables include Dep_old, Dep_young, Life_exp, Health, Inflation, and Interest, whose estimates are omitted for brevity. The lagged Pcgdp is used as an instrumental variable and a threshold variable. The null hypothesis for the first-stage test is that the coefficient on the instrument is zero. 
Table 5 The effect of specific institutional factors - life insurance density

\begin{tabular}{|c|c|c|c|c|c|c|}
\hline \multirow{3}{*}{$\begin{array}{l}\hat{\gamma} \\
\text { C.I. } \\
\text { Sup } W\end{array}$} & \multicolumn{2}{|c|}{$R Q$} & \multicolumn{2}{|c|}{$R L$} & \multicolumn{2}{|c|}{$G E$} \\
\hline & \multicolumn{2}{|c|}{$\begin{array}{c}8.886 \\
{[8.527,9.057]} \\
145.163^{* * *}\end{array}$} & \multicolumn{2}{|c|}{$\begin{array}{c}9.057 \\
{[8.886,9.057]} \\
106.536^{* * *}\end{array}$} & \multicolumn{2}{|c|}{$\begin{array}{c}8.894 \\
{[8.823,9.185]} \\
148.973^{* * *}\end{array}$} \\
\hline & $\operatorname{pcgdp} 0 \leqslant \hat{\gamma}$ & $\operatorname{pcgdp} 0>\hat{\gamma}$ & $\operatorname{pcgdp} 0 \leqslant \hat{\gamma}$ & $\operatorname{pcgdp} 0>\hat{\gamma}$ & $\operatorname{pcgd} p 0 \leqslant \hat{\gamma}$ & $\operatorname{pcgdp} 0>\hat{\gamma}$ \\
\hline Pcgdp & $\begin{array}{l}1.052 * * * \\
(0.111)\end{array}$ & $\begin{array}{l}1.451^{* * *} \\
(0.185)\end{array}$ & $\begin{array}{l}1.327 * * * \\
(0.110)\end{array}$ & $\begin{array}{l}1.352^{* * * *} \\
(0.205)\end{array}$ & $\begin{array}{l}0.894 * * * \\
(0.112)\end{array}$ & $\begin{array}{l}1.199 * * * \\
(0.229)\end{array}$ \\
\hline RQ & $\begin{array}{l}0.995^{* * *} \\
(0.145)\end{array}$ & $\begin{array}{l}0.698 * * * \\
(0.175)\end{array}$ & & & & \\
\hline RL & & & $\begin{array}{l}0.583^{* * * *} \\
(0.130)\end{array}$ & $\begin{array}{l}0.486^{* *} \\
(0.219)\end{array}$ & & \\
\hline GE & & & & & $\begin{array}{l}1.364^{* * *} \\
(0.155)\end{array}$ & $\begin{array}{l}0.636^{* * *} \\
(0.150)\end{array}$ \\
\hline \multirow{2}{*}{$\begin{array}{l}\text { Observations } \\
\text { Adj } R^{2} \\
\text { First-stage test: } p \text {-value }\end{array}$} & \multicolumn{2}{|c|}{0.891} & \multicolumn{2}{|c|}{0.878} & 183 & 113 \\
\hline & 0.000 & 0.000 & 0.000 & 0.000 & 0.000 & 0.000 \\
\hline \multirow{3}{*}{$\begin{array}{l}\hat{\gamma} \\
\text { C.I. } \\
\text { Sup } W\end{array}$} & \multicolumn{2}{|c|}{$V A$} & \multicolumn{2}{|c|}{$P V$} & \multicolumn{2}{|c|}{$C C$} \\
\hline & \multicolumn{2}{|c|}{$\begin{array}{c}9.057 \\
{[8.886,9.185]} \\
145.984^{* * *}\end{array}$} & \multicolumn{2}{|c|}{$\begin{array}{c}9.057 \\
{[8.729,9.057]} \\
150.362 * * *\end{array}$} & \multicolumn{2}{|c|}{$\begin{array}{c}9.057 \\
{[8.552,9.057]} \\
123.701^{* * *}\end{array}$} \\
\hline & $\operatorname{pcgdp} 0 \leqslant \hat{\gamma}$ & $\operatorname{pcgdp} 0>\hat{\gamma}$ & $\operatorname{pcgdp} 0 \leqslant \hat{\gamma}$ & $\operatorname{pcgdp} 0>\hat{\gamma}$ & $\operatorname{pcgdp} 0 \leqslant \hat{\gamma}$ & $\operatorname{pcgdp} 0>\hat{\gamma}$ \\
\hline Pcgdp & $\begin{array}{l}1.147^{* * *} \\
(0.123)\end{array}$ & $\begin{array}{l}1.627^{* * *} \\
(0.186)\end{array}$ & $\begin{array}{l}1.301 * * * \\
(0.107)\end{array}$ & $\begin{array}{l}1.659 * * * \\
(0.187)\end{array}$ & $\begin{array}{l}1.262 * * * \\
(0.123)\end{array}$ & $\begin{array}{l}1.486^{* * *} \\
(0.213)\end{array}$ \\
\hline VA & $\begin{array}{l}0.629 * * * \\
(0.140)\end{array}$ & $\begin{array}{l}1.026^{* * *} \\
(0.223)\end{array}$ & & & & \\
\hline PV & & & $\begin{array}{l}0.418^{* * * *} \\
(0.107)\end{array}$ & $\begin{array}{r}-0.218 \\
(0.149)\end{array}$ & & \\
\hline $\mathrm{CC}$ & & & & & $\begin{array}{l}0.582^{* * *} \\
(0.151)\end{array}$ & $\begin{array}{c}0.155 \\
(0.149)\end{array}$ \\
\hline Observations & 187 & 109 & 187 & 109 & 187 & 109 \\
\hline $\operatorname{Adj} R^{2}$ & \multicolumn{2}{|c|}{0.886} & \multicolumn{2}{|c|}{0.875} & \multicolumn{2}{|c|}{0.874} \\
\hline First-stage test: $p$-value & 0.000 & 0.000 & 0.000 & 0.000 & 0.000 & 0.000 \\
\hline
\end{tabular}

***Significant at the 1 per cent level; **Significant at the 5 per cent level; *Significant at the 10 per cent level.

Notes: Standard errors in parentheses. $\hat{\gamma}$ is the estimated threshold value, C.I. is the confidence interval corresponding to the estimated threshold value, and Sup $W$ is the largest value of a series of the Wald statistics estimated under different threshold values. The dependent variable is life insurance density in the natural logarithm form. Pcgdp is the natural logarithm of real GDP per capita. RQ is regulatory quality. RL is rule of law. GE is government effectiveness. VA is Voice and accountability. $\mathrm{PV}$ is political stability and absence of violence. $\mathrm{CC}$ is control of corruption. Controlling variables include Dep_old, Dep_young, Life_exp, Health, Inflation, and Interest, whose estimates are omitted for brevity. The lagged Pcgdp is used as an instrumental variable and a threshold variable. The null hypothesis for the first-stage test is that the coefficient on the instrument is zero. 
countries at the 1 per cent significance level except for $\mathrm{PV}$ that is significant at 5 per cent for penetration. However, the significance of specific governance indicators is not so strong for the high-income regime. The coefficients are significant only in one governance indicator for penetration and four for density. In addition to statistical significance, the coefficients of governance indicators are also larger in magnitude for low-income countries except for voice and accountability. The results overall indicate that the legal and political environments exert a larger impact on life insurance activities in low-income countries.

\section{Robustness check}

In this subsection we perform some additional analyses to confirm the robustness of our findings above. First, as noted in the data subsection, our observations diminish, from 716 to 296 , when we include all control variables into the model. To verify that this information loss does not alter the findings above, we redo all analyses by utilising the sample including all control variables. The results are qualitatively the same and our findings are thus robust.

Second, we consider alternative institutional variables. Information accuracy is an important environment for the demand of life insurance. We use La Porta et al.' ${ }^{64}$ disclosure requirements index and liability standard index to examine if similar findings emerge when alternative dimensions of the institutional environment are considered. Column (1) in Table 6 shows that the effect of the disclosure requirement and liability standard on the development of life insurance markets is significantly positive for lower-income countries, but is insignificant for higher-income countries. Therefore, the findings above are sustainable even when using alternative institutional measurements.

Third, to further verify if the effect of institutional environments on life insurance development diminishes with an increase in the degree of economic development, we examine the impact of the interaction terms of institution and economic development. As shown in column (2) of Table 6, the coefficient of institution is significantly positive but the coefficient on the interaction term is negative for the high-income regime. This evidence supports the view that institution matters for the development of life insurance markets, but the institution's impact is tempered by economic development.

Fourth, in previous analyses we omit some important variables in determining the demand for life insurance due to the requirement for including as many observations as possible. To check the robustness of our results, we include related determinants documented by prior research, including overall dependency ratio (Dep), banking sector development (Dba_gdp), savings rate

\footnotetext{
${ }^{64}$ La Porta et al. (2006).
} 
Table 6 Robustness checks - life insurance density

\begin{tabular}{|c|c|c|c|c|c|c|c|c|}
\hline \multirow{4}{*}{$\begin{array}{l}\hat{\gamma} \\
\text { C.I. } \\
\text { Sup W }\end{array}$} & \multicolumn{4}{|c|}{ (1) Alternative institutional variables } & \multirow{2}{*}{\multicolumn{2}{|c|}{$\begin{array}{c}\text { (2) Interaction of } \\
\text { institution and economic } \\
\text { development }^{a}\end{array}$}} & \multirow{2}{*}{\multicolumn{2}{|c|}{$\begin{array}{c}\text { (3) Additional control } \\
\text { variables }^{b}\end{array}$}} \\
\hline & \multicolumn{2}{|c|}{ Disclosure requirement ${ }^{a}$} & \multicolumn{2}{|c|}{$\begin{array}{l}\text { Liability } \\
\text { standard }^{a}\end{array}$} & & & & \\
\hline & \multicolumn{2}{|c|}{$\begin{array}{c}9.426 \\
{[9.426,9.990]} \\
136.980 * * *\end{array}$} & \multicolumn{2}{|c|}{$\begin{array}{c}9.601 \\
{[9.426,9.877]} \\
162.692 * * *\end{array}$} & \multicolumn{2}{|c|}{$\begin{array}{c}9.057 \\
{[7.938,9.302]} \\
137.666^{* * *}\end{array}$} & \multicolumn{2}{|c|}{$\begin{array}{c}8.232 \\
{[8.222,8.526]} \\
102.626^{* * *}\end{array}$} \\
\hline & $p \operatorname{cgd} p 0 \leqslant \gamma$ & $p \operatorname{cgd} 0>\gamma$ & $p c g d p 0 \leqslant \gamma$ & $p \operatorname{cgd} 0>\gamma$ & $p \operatorname{cgd} 0 \leqslant \gamma$ & $p c g d p 0>\gamma$ & $p c g d p 0 \leqslant \gamma$ & $p \operatorname{cgd} 00>\gamma$ \\
\hline Pcgdp & $\begin{array}{l}1.462 * * * \\
(0.100)\end{array}$ & $\begin{array}{l}1.438 * * * \\
(0.224)\end{array}$ & $\begin{array}{l}1.425^{* * *} \\
(0.103)\end{array}$ & $\begin{array}{l}1.064 * * * \\
(0.208)\end{array}$ & $\begin{array}{l}1.104 * * * \\
(0.128)\end{array}$ & $\begin{array}{l}3.400 * * * \\
(0.758)\end{array}$ & $\begin{array}{c}0.443 \\
(0.371)\end{array}$ & $\begin{array}{l}1.672 * * * \\
(0.135)\end{array}$ \\
\hline Institution & & & & & $\begin{array}{c}0.648 \\
(1.098)\end{array}$ & $\begin{array}{l}15.599 * * * \\
(5.390)\end{array}$ & $\begin{array}{l}1.018^{* *} \\
(0.485)\end{array}$ & $\begin{array}{c}-0.055 \\
(0.194)\end{array}$ \\
\hline Disclose & $\begin{array}{l}1.713^{* * *} \\
(0.300)\end{array}$ & $\begin{array}{c}-0.497 \\
(0.353)\end{array}$ & & & & & & \\
\hline Bdn_proof & & & $\begin{array}{l}1.999 * * * \\
(0.227)\end{array}$ & $\begin{array}{c}-0.388 \\
(0.247)\end{array}$ & & & & \\
\hline Insti*Pcgdp & & & & & $\begin{array}{c}0.041 \\
(0.130)\end{array}$ & $\begin{array}{c}-1.522 * * * \\
(0.543)\end{array}$ & & \\
\hline Dep & & & & & & & $\begin{array}{c}0.015 \\
(0.019)\end{array}$ & $\begin{array}{c}-0.057^{* * *} \\
(0.008)\end{array}$ \\
\hline Dba_gdp & & & & & & & $\begin{array}{l}5.171 * * \\
(2.222)\end{array}$ & $\begin{array}{c}0.690^{*} \\
(0.387)\end{array}$ \\
\hline Saving & & & & & & & $\begin{array}{c}0.027 \\
(0.025)\end{array}$ & $\begin{array}{c}0.028^{*} \\
(0.015)\end{array}$ \\
\hline M2_gdp & & & & & & & $\begin{array}{r}-0.033 \\
(0.027)\end{array}$ & $\begin{array}{r}-0.003 \\
(0.002)\end{array}$ \\
\hline Secondary & & & & & & & $\begin{array}{l}0.015^{* *} \\
(0.006)\end{array}$ & $\begin{array}{c}-0.006^{*} \\
(0.004)\end{array}$ \\
\hline Idv & & & & & & & $\begin{array}{c}0.001 \\
(0.010)\end{array}$ & $\begin{array}{l}0.008^{* *} \\
(0.003)\end{array}$ \\
\hline Observation & 91 & 82 & 100 & 73 & 187 & 109 & 69 & 110 \\
\hline Adj $R^{2}$ & & 54 & & 57 & & 87 & 0.9 & 25 \\
\hline
\end{tabular}

${ }^{\mathrm{a}}$ Control variables include Dep_old, Dep_young, Life_exp, Health, Inflation, and Interest.

${ }^{\mathrm{b}}$ Other control variables include Life_exp, Health, Inflation, and Interest.

***Significant at the 1 per cent level; ${ }^{* *}$ Significant at the 5 per cent level; *Significant at the 10 per cent level.

Notes: Standard errors in parentheses. $\hat{\gamma}$, C.I., and Sup $W$ are defined as Table 3. The dependent variable is the natural logarithm of life insurance density. For the definition of explanatory variables, please see Table 3 and Appendix B. All first-stage tests on the instrument are significant and not reported to save space.

(Saving), financial development (M2_gdp), education levels (Secondary), and national culture (Idv). As shown in column (3) of Table 6, the effect of institutions is significantly positive for lower-income countries, but mixed for higher-income countries, which is consistent with the findings above. 
Finally, to verify if our findings hold in the multiple threshold case, we follow the procedure proposed in Hansen ${ }^{65}$ to estimate the two thresholds model. ${ }^{66}$ As Table 7 shows, the coefficients on institution are significantly positive and largest for countries situated in the lowest income regime (see the column under $\operatorname{pcgdp} 0 \leqslant \gamma^{\prime}$ and $\gamma^{\prime}<\operatorname{pcgdp} 0 \leqslant \gamma$ in Panel A). Moreover, the coefficients on the income variable show that the effect of income on life insurance consumption is larger at the middle level (see the column under $\gamma^{\prime}<\operatorname{pcgdp} 0 \leqslant \gamma$ in Panel A and the column under $\gamma<\operatorname{pcgdp} 0 \leqslant \gamma^{\prime \prime}$ in Panel B) than at the other two sides (see the column under pcgdp $0 \leqslant \gamma^{\prime}$ in Panel A and the column under pcgdp $0>\gamma^{\prime \prime}$ in Panel B). ${ }^{67}$ This result reflects an S-curve pattern and lends support to Enz's ${ }^{9}$ view that the income elasticity of demand for insurance is equal to one at a specific low-income level, but may reach two or greater at intermediate income levels, because insurance density and income here are measured in logarithmic form and thus the coefficient represents the income elasticity of demand. ${ }^{68}$

\section{Cross-country analysis}

To examine whether our findings above hold across countries, we perform the same analysis by averaging data over the sample period such that there is one observation for each country. We require at least three-year observations for each country to avoid the influence of a single event, which reduces our sample to 62 countries. As presented in Table 8, the results based on life insurance penetration show that a significant income threshold effect still exists and that the institutional environment plays an important role on the development of life insurance markets mainly in low-income countries.

The results on life insurance density are, however, not robust. Some possible reasons are as follows. First, averaging data may lead to the loss of some

${ }^{65}$ Hansen (2000).

${ }^{66}$ According to Hansen (2000), the second threshold could be determined in a sequential manner. After determining the first threshold and splitting the sample into two subsamples, the same analysis can mechanically be performed on each subsample to determine the second threshold. Hansen notes that theoretical results of this procedure are not clear, because the threshold model is developed under the framework of a single threshold, but the procedure can still provide some informative results.

${ }^{67}$ Our results here show that there are three thresholds in the spectrum of the full sample. However, this does not mean the S-curve pattern does not hold, because, as Hansen (2000) notes, the theoretical results for determining thresholds sequentially are not clear. Rather, the results generate some informative implications. That is, the relationship between the income level and life insurance consumption is more complicated when other determinants are taken into account.

${ }^{68}$ Robustness tests for life insurance penetration are qualitatively similar to those of life insurance density. The results are not reported to save space, but available from the authors upon request. 
Table 7 Double thresholds - life insurance density

Panel A: Second sample split based on sub-sample with Pcgdp0 under the first threshold $(\hat{\gamma}=8.886)$

\begin{tabular}{|c|c|c|c|}
\hline \multirow[t]{2}{*}{$\begin{array}{l}\hat{\gamma}^{\prime} \\
\text { C.I. } \\
\text { Sup W }\end{array}$} & \multicolumn{3}{|c|}{$\begin{array}{c}8.232 \\
{[7.658,8.286]} \\
89.501 * * *\end{array}$} \\
\hline & $p c g d p 0 \leqslant \gamma^{\prime}$ & $\gamma^{\prime}<p c g d p 0 \leqslant \gamma$ & $p c g d p 0>\gamma$ \\
\hline Pcgdp & $\begin{array}{l}0.910 * * * \\
(0.183)\end{array}$ & $\begin{array}{l}2.247 * * * \\
(0.436)\end{array}$ & $\begin{array}{l}1.601 * * * \\
(0.198)\end{array}$ \\
\hline Institution & $\begin{array}{l}1.359 * * * \\
(0.281)\end{array}$ & $\begin{array}{l}0.402 * * \\
(0.169)\end{array}$ & $\begin{array}{l}0.443^{* *} \\
(0.206)\end{array}$ \\
\hline Observation & 111 & 71 & 114 \\
\hline $\operatorname{Adj} R^{2}$ & 0.669 & 0.755 & 0.662 \\
\hline First-stage test: $p$-value & 0.000 & 0.000 & 0.000 \\
\hline
\end{tabular}

Panel B: Second sample split based on sub-sample with Pcgdp0 over the first threshold $(\hat{\gamma}=8.886)$

\begin{tabular}{lccc}
\hline$\hat{\gamma}^{\prime \prime}$ & \multicolumn{3}{c}{10.105} \\
C.I. & & {$[9.936,10.119]$} \\
Sup $W$ & $82.949^{* * * *}$ \\
\cline { 2 - 4 } & $p c g d p 0 \leqslant \gamma$ & $\gamma<p c g d p 0 \leqslant \gamma^{\prime \prime}$ & $p c g d p 0>\gamma^{\prime \prime}$ \\
\hline Pcgdp & $0.988^{* * *}$ & $1.974^{* * *}$ & 0.649 \\
& $(0.119)$ & $(0.353)$ & $(0.467)$ \\
Institution & $1.080^{* * *}$ & 0.309 & 0.119 \\
& $(0.164)$ & $(0.228)$ & $(0.275)$ \\
Observation & & & 45 \\
Adj $R^{2}$ & 182 & 69 & 0.818 \\
First-stage test: $p$-value & 0.742 & 0.665 & 0.000 \\
\hline
\end{tabular}

***Significant at the 1 per cent level; **Significant at the 5 per cent level; *Significant at the 10 per cent level.

Notes: Standard errors in parentheses. $\hat{\gamma}$ is the estimated threshold value, C.I. is the confidence interval corresponding to the estimated threshold value, and Sup $W$ is the largest value of a series of the Wald statistics estimated under different threshold values. The dependent variable is the logarithm of life insurance density. Pcgdp is the natural logarithm of real GDP per capita. Institution is the average of six indicators measuring voice and accountability, political stability, government effectiveness, regulatory quality, rule of law, and control of corruption. Control variables include Dep_old, Dep_young, Life_exp, Health, Inflation, and Interest as included in Table 3.

information on insurance development and institutional quality. The extent of information loss may be larger for life insurance density, because it represents the amount of money, as opposed to life insurance penetration indicating a 
Table 8 Cross-section analysis - life insurance penetration

\begin{tabular}{|c|c|c|c|c|c|c|}
\hline \multirow{3}{*}{$\begin{array}{l}\hat{\gamma} \\
\text { C.I. } \\
\text { Sup W }\end{array}$} & \multicolumn{2}{|c|}{$R Q$} & \multicolumn{2}{|c|}{$R L$} & \multicolumn{2}{|c|}{$G E$} \\
\hline & \multicolumn{2}{|c|}{$\begin{array}{c}8.596 \\
{[8.596,8.714]} \\
86.957 * * *\end{array}$} & \multicolumn{2}{|c|}{$\begin{array}{c}8.614 \\
{[8.596,8.714]} \\
101.951 * * *\end{array}$} & \multicolumn{2}{|c|}{$\begin{array}{c}8.614 \\
{[8.596,8.714]} \\
88.039 * *\end{array}$} \\
\hline & $p c g d p 0 \leqslant \hat{\gamma}$ & $p c g d p 0>\hat{\gamma}$ & $p c g d p 0 \leqslant \hat{\gamma}$ & $p c g d p 0>\hat{\gamma}$ & $p c g d p 0 \leqslant \hat{\gamma}$ & $p c g d p 0>\hat{\gamma}$ \\
\hline Pcgdp & $\begin{array}{l}1.444 * * \\
(0.582)\end{array}$ & $\begin{array}{l}3.006^{* * *} \\
(0.654)\end{array}$ & $\begin{array}{l}1.696^{* * *} \\
(0.620)\end{array}$ & $\begin{array}{l}2.702 * * * \\
(0.672)\end{array}$ & $\begin{array}{l}1.186^{* *} \\
(0.547)\end{array}$ & $\begin{array}{l}2.628^{* * * *} \\
(0.680)\end{array}$ \\
\hline RQ & $\begin{array}{c}0.904 * \\
(0.487)\end{array}$ & $\begin{array}{c}1.496 \\
(1.105)\end{array}$ & & & & \\
\hline RL & & & $\begin{array}{c}0.369 \\
(0.334)\end{array}$ & $\begin{array}{c}1.359 \\
(1.185)\end{array}$ & & \\
\hline GE & & & & & $\begin{array}{l}1.357^{* * *} \\
(0.487)\end{array}$ & $\begin{array}{c}1.126 \\
(0.734)\end{array}$ \\
\hline \multirow{3}{*}{$\begin{array}{l}\text { Observations } \\
\text { Adj } R^{2} \\
\text { First-stage test: } p \text {-value }\end{array}$} & \multicolumn{2}{|c|}{0.633} & \multicolumn{2}{|c|}{0.628} & \multicolumn{2}{|c|}{0.643} \\
\hline & 0.000 & 0.000 & 0.000 & 0.000 & 0.000 & 0.000 \\
\hline & & & & & & \\
\hline \multirow[t]{2}{*}{$\begin{array}{l}\hat{\gamma} \\
\text { C.I. } \\
\text { Sup W }\end{array}$} & \multicolumn{2}{|c|}{$\begin{array}{c}8.596 \\
{[8.596,8.614]} \\
120.848 * * *\end{array}$} & \multicolumn{2}{|c|}{$\begin{array}{c}8.614 \\
{[8.596,8.714]} \\
100.329 * * *\end{array}$} & \multicolumn{2}{|c|}{$\begin{array}{c}8.614 \\
{[8.596,8.714]} \\
95.157 * * *\end{array}$} \\
\hline & $p c g d p 0 \leqslant \hat{\gamma}$ & $p c g d p 0>\hat{\gamma}$ & $p c g d p 0 \leqslant \hat{\gamma}$ & $p c g d p 0>\hat{\gamma}$ & $p c g d p 0 \leqslant \hat{\gamma}$ & $p c g d p 0>\hat{\gamma}$ \\
\hline Pcgdp & $\begin{array}{l}1.490^{* * *} \\
(0.480)\end{array}$ & $\begin{array}{l}3.423^{* * *} \\
(0.611)\end{array}$ & $\begin{array}{l}1.530 * * \\
(0.620)\end{array}$ & $\begin{array}{l}3.411 * * * \\
(0.678)\end{array}$ & $\begin{array}{l}1.421^{* *} \\
(0.555)\end{array}$ & $\begin{array}{l}3.364^{* * *} \\
(0.910)\end{array}$ \\
\hline VA & $\begin{array}{c}0.628^{*} \\
(0.341)\end{array}$ & $\begin{array}{c}1.562 \\
(1.178)\end{array}$ & & & & \\
\hline PV & & & $\begin{array}{c}0.555^{*} \\
(0.319)\end{array}$ & $\begin{array}{c}0.102 \\
(0.670)\end{array}$ & & \\
\hline $\mathrm{CC}$ & & & & & $\begin{array}{l}0.878^{* *} \\
(0.385)\end{array}$ & $\begin{array}{c}0.062 \\
(0.948)\end{array}$ \\
\hline Observations & 35 & 27 & 36 & 26 & 36 & 26 \\
\hline $\operatorname{Adj} R^{2}$ & \multicolumn{2}{|c|}{0.632} & \multicolumn{2}{|c|}{0.624} & \multicolumn{2}{|c|}{0.624} \\
\hline First-stage test: $p$-value & 0.000 & 0.000 & 0.000 & 0.000 & 0.000 & 0.000 \\
\hline
\end{tabular}

***Significant at the 1 per cent level; **Significant at the 5 per cent level; *Significant at the 10 per cent level.

Notes: Standard errors in parentheses. $\hat{\gamma}$ is the estimated threshold value, C.I. is the confidence interval corresponding to the estimated threshold value, and Sup $W$ is the largest value of a series of the Wald statistics estimated under different threshold values. The dependent variable is insurance penetration. Pcgdp is the natural logarithm of real GDP per capita. RQ is regulatory quality. RL is rule of law. GE is government effectiveness. VA is Voice and accountability. PV is political stability and absence of violence. CC is control of corruption. Controlling variables include Dep_old, Dep_young, Life_exp, Health, Inflation, and Interest, whose estimates are omitted for brevity. The lagged Pcgdp is used as an instrumental variable and a threshold variable. The null hypothesis for the first-stage test is that the coefficient on the instrument is zero. 
ratio. The difference between the mean and the level should be larger for the amount than for the ratio when the ratio changes slowly. Although averaging data has an advantage of removing the business cycle effect, this problem is not serious in our data set in that the sample period of our full model covers only five years. Second, the evolvement of institutions varies over time within and across countries. Tressel and Detragiache ${ }^{69}$ note that financial reforms may progress at a smooth and gradual pace rather than through one-off, "big bang" events, and thus averaging data may hide the effect of gradual reforms. The evolvement of institutional quality, like reforms, should also follow a smooth and gradual process. Hence, evaluating average levels of insurance development over arbitrarily defined periods may conceal the effect of gradual institutional improvement.

\section{Summary and conclusions}

This article reinvestigates the non-linear relationship between real income level and the demand for life insurance and examines whether the effect of institutional environments on life insurance development varies at different stages of economic development. Using a pooling sample of 92 economies over the period 1996-2008, we utilise a threshold regression model along with the instrumental variable approach developed in Caner and Hansen ${ }^{15}$ to empirically verify this non-linearity and the divergent effect of institutional conditions.

Using real GDP per capita as the measure of economic development, we find that national income is positively correlated with life insurance activities, and the effect is higher for high-income countries than it is for low-income countries. Moreover, legal and political conditions have a more significant influence on life insurance activities in low-income countries, corresponding somewhat to the findings of Ward and Zurbruegg ${ }^{13}$ who document that the effects of legal and political environments on life insurance consumption in emerging countries are higher than in developed countries in some specifications.

Our study complements earlier literature in several aspects. First, our adoption of the perception-based measure of institutional environments confirms the relevance of the de facto aspect of legal and political circumstances, suggesting that the de facto aspect that exists on the ground is at least as important as the de jure aspect of laws on the books for the development of the life insurance market, especially for low-income countries. Second, Carter and Dickinson ${ }^{8}$ and Enz ${ }^{9}$ depict an S-curve shape between insurance development and economic development through

\footnotetext{
${ }^{69}$ Tressel and Detragiache (2008).
} 
the perspective on economic theory or economic intuition. The non-linear framework utilised in our article empirically verifies the existence of this pattern. Finally, Outreville ${ }^{45}$ finds that good governance environments exert a strong impact on the choice of countries to operate by the world finance and insurance groups. Our findings somewhat complement this observation from an alternative perspective. That institutional environments are more relevant for less developed countries implies that improving the institutional conditions should be a channel for these economies to attract foreign insurers to enter domestic insurance markets. The participation of foreign insurers may stimulate the development of local insurance markets. $^{70}$

\section{Acknowledgements}

The authors would like to thank the Editor, Professor Wambach and two anonymous referees for their highly constructive comments. We are also grateful to the National Science Council of Taiwan for financial support through grant NSC 100-2410-H-110-027-MY2.

\section{References}

Arestis, P., Demetriades, P.O. and Luintel, B. (2001) 'Financial development and economic growth: The role of stock markets', Journal of Money, Credit, and Banking 33(1): 16-41.

Atje, R. and Jovanovic, B. (1993) 'Stock markets and development', European Economic Review 37: 632-640.

Avram, K., Nguyen, Y. and Skully, M. (2010) Insurance and economic growth: A cross country examination, Working Paper, Monash University.

Beck, T. and Demirgüç-Kunt, A. (2009) Financial institutions and markets across countries and over time: Data and analysis Policy Research Working Paper No. 4943, The World Bank, Washington, DC.

Beck, T. and Webb, I. (2003) 'Economic, demographic, and institutional determinants of life insurance consumption across countries', World Bank Economic Review 17(I): 51-88.

Beenstock, M., Dickinson, G. and Khajuria, S. (1986) 'The determination of life premiums: An international cross-section analysis', 1970-1981 Insurance: Mathematics and Economics 5: 261-270.

Bernheim, B.D. (1991) 'How strong are bequest motives? Evidence based on estimates of the demand for life insurance and annuities', Journal of Political Economy 99: 899-927.

Bonini, S. and Alkan Aktuccar, S. (2009) 'The macro and political determinants of venture capital investments around the World', SSRN eLibrary.

${ }^{70}$ Browne et al. (2000) find that the market share held by foreign insurers is positively correlated with the purchase of general liability insurance. Feyen et al. (2011) indicate that the presence of foreign insurers is expected to contribute to the development of insurance markets through product innovation and marketing techniques, although empirical results are mixed. Lee and Chang (2011) exemplify that the participation of foreign insurers has benefited the growth of life insurance markets in China and India. 
Browne, M.J., Chung, J. and Frees, E.W. (2000) 'International property-liability insurance consumption', Journal of Risk \& Insurance 67(1): 73-90.

Browne, M.J. and Kim, K. (1993) 'An international analysis of life insurance demand', Journal of Risk and Insurance 60: 616-634.

Caner, M. and Hansen, B.E. (2004) 'Instrumental variable estimation of a threshold model', Econometric Theory 20: 813-843.

Carter, R.L. and Dickinson, G.M. (1992) Obstacles to the Liberalisation of Trade in Insurance, London: Harvester Wheatsheaf.

Enz, R. (2000) 'The S-curve relation between per-capita income and insurance penetration', The Geneva Papers on Risk and Insurance - Issues and Practice 25: 396-406.

Esho, N., Kirievsky, A., Ward, D. and Zurbruegg, R. (2004) 'Law and the determinants of property-casualty insurance', Journal of Risk and Insurance 71: 265-283.

Ferber, R. and Lee, L.C. (1980) 'Acquisition and accumulation of life insurance in early married life', Journal of Risk and Insurance 47: 713-734.

Feyen, E., Lester, R. and Rocha, R. (2011) What drives the development of the insurance sector? An empirical analysis based on a panel of developed and developing countries, Policy Research Working Paper No. 5572, The World Bank, Washington, DC.

Fischer, S. (1973) 'A life cycle model of life insurance purchases', International Economic Review 14: $132-152$.

Fortune, P. (1973) 'A theory of optimal life insurance: Development and tests', Journal of Finance 28(3): 587-600.

Hakansson, N.H. (1969) 'Optimal investment and consumption strategies under risk, and uncertain lifetime and insurance', International Economic Review 10: 443-466.

Hammond, J.D., Houston, D.B. and Melander, E.R. (1967) 'Determinants of household life insurance premium expenditures: An empirical investigation', Journal of Risk and Insurance 34: 397-408.

Han, L., Li, D., Moshirian, F. and Tian, L. (2010) 'Insurance development and economic growth', Geneva Papers on Risk and Insurance - Issues and Practice 35: 183-199.

Hansen, B.E. (1996) 'Inference when a nuisance parameter is not identified under the null hypothesis', Econometrica 64: 413-430.

Hansen, B.E. (2000) 'Sample splitting and threshold estimation', Econometrica 68(3): 575-603.

Higgins, M. and Thistle, P.D. (2000) 'Capacity constraints and the dynamics of underwriting profits', Economic Inquiry 38(3): 442-457.

Hofstede, G. (1995) 'Insurance as a product of national values', Geneva Papers on Risk and Insurance-Issues and Practice 20(4): 423-429.

Hussels, S., Ward, D. and Zurbruegg, R. (2005) 'Stimulating the demand for insurance', Risk Management and Insurance Review 8: 257-278.

Jawadi, F., Bruneau, C. and Sghaier, N. (2009) 'Nonlinear cointegration relationships between non-life insurance premiums and financial markets', Journal of Risk and Insurance 76: 753-783.

Kaufmann, D., Kraay, A. and Mastruzzi, M. (2005) Governance matters IV: Governance indicators for 1996-2004, Policy Research Working Paper No. 3630, The World Bank, Washington, DC.

Kaufmann, D., Kraay, A. and Mastruzzi, M. (2009) Governance matters VIII: Aggregate and individual governance indicators, 1996-2008, Policy Research Working Paper No. 4978, The World Bank, Washington, DC.

Kaufmann, D., Kraay, A. and Zoido-Lobatón, P. (1999) Aggregating governance indicators, Policy Research Working Paper No. 2195, The World Bank, Washington, DC.

King, R.G. and Levine, R. (1993) 'Finance and growth: Schumpeter might be right', Quarterly Journal of Economics 108: 717-737.

La Porta, R., Lopez-de-Silanes, F. and Shleifer, A. (2006) 'What works in securities laws', Journal of Finance 61(1): 1-32. 
Lee, C.C. (2011) 'Insurance and real output: The key role of banking activities', Macroeconomic Dynamics, advance online publication 4 November 2011, doi:10.1017/S1365100511000101.

Lee, C.C. and Chang, C.H. (2011) 'Globalization and convergence of international life insurance markets', Geneva Papers on Risk and Insurance-Issues and Practice, doi:10.1057/ gpp.2011.34.

Leng, C.C., Powers, M.R. and Venezian, E.C. (2002) 'Did regulation change competitiveness in property-liability insurance? Evidence from underwriting profit and investment income', Journal of Insurance Regulation 21(2): 57-77.

Levine, R. (1997) 'Financial development and economic growth: Views and agenda', Journal of Economic Literature 35: 688-726.

Levine, R. and Zervos, S. (1996) 'Stock market development and long-run growth', The World Bank Economic Review 10: 323-339.

Levine, R. and Zervos, S. (1998) 'Stock markets, banks, and economic growth', American Economic Review 88: 537-558.

Lewis, F.D. (1989) 'Dependents and the demand for life insurance', American Economic Review 79: $452-467$.

Outreville, J.F. (1991) 'The relationship between insurance, financial development and market structure in developing countries', UNTCAD Review 3(1): 53-69.

Outreville, J.F. (1996) 'Life insurance markets in developing countries', Journal of Risk and Insurance 63: 263-278.

Outreville, J.F. (1999) Financial development, human capital and political instability, UNCTAD Discussion paper (No. 142).

Outreville, J.F. (2007) 'Foreign affiliates of the world largest financial groups: Locations and governance', Research in International Business and Finance 21(1): 19-31.

Outreville, J.F. (2008) 'Foreign affiliates of the largest insurance groups: Location-specific advantages', Journal of Risk and Insurance 75: 463-491.

Pistor, K., Raiser, M. and Gelfer, S. (2000) 'Law and finance in transition economies', Economics of Transition 8: 325-368.

Roe, M.J. and Siegel, J.I. (2011) 'Political instability: Effects on financial development, roots in the severity of economic inequality', Journal of Comparative Economics 39(3): 279-309.

Sen, S. (2008) An analysis of life insurance demand determinants for selected Asian Economies and India, MSE Working Papers, 36, Madras School of Economics.

Shen, C.H. and Lee, C.C. (2006) 'Same financial development yet different economic growth why?', Journal of Money, Credit, and Banking 38(7): 1907-1944.

Tressel, T. and Detragiache, E. (2008) Do financial sector reforms lead to financial development? Evidence from a new dataset, IMF Working Paper.

Truett, D.B. and Truett, L.J. (1990) 'The demand for life insurance in Mexico and the United States: A comparative study', Journal of Risk and Insurance 57: 321-328.

Tsay, R.S. (2005) Analysis of Financial Time Series 2nd edn., New Jersey: John Wiley \& Sons.

UNDP (2008) A User's Guide to Measuring Corruption, First Edition edn., Oslo, Norway: United Nations Development Programme.

Ward, D. and Zurbruegg, R. (2000) 'Does insurance promote economic growth? Evidence from OECD economies', Journal of Risk and Insurance 67: 489-506.

Ward, D. and Zurbruegg, R. (2002) 'Law, politics and life insurance consumption in Asia', The Geneva Papers on Risk and Insurance - Issues and Practice 27: 395-412.

Wasaw, B. and Hill, R.D. (1986) The Insurance Industry in Economic Development, New York: New York University Press.

Webb, I., Grace, M.F. and Skipper, H.D. (2002) The effect of banking and insurance on the growth of capital and output, Center for Risk Management and Insurance, Working Paper 02-1, Georgia State University. 
Wen, G.J. and Zhang, C. (1993) 'Investment under risk in property rights', China Economic Review 4(1): 49-53.

World Development Indicators (2010) World Development Report, Washington, DC: The World Bank.

Yaari, M.E. (1965) 'Uncertain lifetime, life insurance, and the theory of the consumer', Review of Economic Studies 32: 137-150.

Zelizer, V.R. (1979) Morals and Markets: The Development of Life Insurance in the United States, New York: Columbia University Press.

Zheng, W., Liu, Y. and Deng, Y. (2009) 'A comparative study of international insurance markets', Geneva Papers on Risk and Insurance - Issues and Practice 34(1): 85-99.

Zietz, E.N. (2003) 'An examination of the demand for life insurance', Risk Management and Insurance Review 6: 159-191.

\section{Appendix A}

Table A1 Economic entities included in this study

\begin{tabular}{lll}
\hline Algeria & Honduras & Pakistan \\
Argentina & Hong Kong, China & Panama \\
Australia & Hungary & Peru \\
Austria & Iceland & Philippines \\
Bahrain & India & Poland \\
Bangladesh & Indonesia & Portugal \\
Barbados & Iran, Islamic Rep. & Qatar \\
Belgium & Ireland & Romania \\
Botswana & Israel & Russian Federation \\
Brazil & Italy & Saudi Arabia \\
Bulgaria & Jamaica & Singapore \\
Canada & Japan & Slovak Republic \\
Chile & Jordan & Slovenia \\
China & Kazakhstan & South Africa \\
Colombia & Kenya & Spain \\
Costa Rica & Korea, Rep. & Sri Lanka \\
Côte d'Ivoire & Kuwait & Sweden \\
Croatia & Latvia & Switzerland \\
Cyprus & Lebanon & Thailand \\
Czech Republic & Lithuania & Trinidad and Tobago \\
Denmark & Luxembourg & Tunisia \\
Dominican Republic & Malaysia & Turkey \\
Ecuador & Malta & Ukraine \\
Egypt, Arab Rep. & Mauritius & United Arab Emirates \\
El Salvador & Mexico & United Kingdom \\
Estonia & Morocco & United States \\
Finland & Namibia & Uruguay \\
France & Netherlands & Venezuela, RB \\
Germany & New Zealand & Vietnam \\
Greece & Norway & Zimbabwe \\
Guatemala & Oman & \\
\hline & & \\
\hline & & \\
\hline
\end{tabular}




\section{Appendix B}

Table B1 Definitions and sources of variables

\begin{tabular}{|c|c|c|}
\hline Variable & Definition & Sources \\
\hline Penetration & $\begin{array}{l}\text { Life insurance premium volume as a share } \\
\text { of GDP }\end{array}$ & $\begin{array}{l}\text { Financial Structure Dataset by Beck and } \\
\text { Demirgüç-Kunt. Premium data is taken } \\
\text { from various issues of Sigma reports. } \\
\text { Data on GDP in U.S. dollars. }\end{array}$ \\
\hline Density & $\begin{array}{l}\text { Life insurance premium per capita in U.S. } \\
\text { dollars (in natural logarithm) }\end{array}$ & $\begin{array}{l}\text { Author's calculation using Financial } \\
\text { Structure Dataset }\end{array}$ \\
\hline Pcgdp & $\begin{array}{l}\text { GDP per capita in } 2,000 \text { U.S. dollars (in } \\
\text { natural logarithm) }\end{array}$ & $\begin{array}{l}\text { World Development Indicators (WDI), } \\
\text { The World Bank }\end{array}$ \\
\hline Institution & $\begin{array}{l}\text { Average of six indicators measuring voice } \\
\text { and accountability, political stability, } \\
\text { government effectiveness, regulatory } \\
\text { quality, rule of law, and control of } \\
\text { corruption. }\end{array}$ & Kaufmann et al. (2009) \\
\hline VA & Voice and accountability & Kaufmann et al. (2009) \\
\hline PV & Political stability and absence of violence & Kaufmann et al. (2009) \\
\hline GE & Government effectiveness & Kaufmann et al. (2009) \\
\hline RQ & Regulatory quality & Kaufmann et al. (2009) \\
\hline RL & Rule of law & Kaufmann et al. (2009) \\
\hline $\mathrm{CC}$ & Control of corruption & Kaufmann et al. (2009) \\
\hline Dep_old & $\begin{array}{l}\text { Old dependency ratio, ratio of the } \\
\text { population older than } 64 \text { to the population } \\
\text { of ages } 15-64\end{array}$ & WDI, The World Bank \\
\hline Dep_young & $\begin{array}{l}\text { Young dependency ratio, ratio of the } \\
\text { population younger than } 15 \text { to the } \\
\text { population of ages } 15-64\end{array}$ & WDI, The World Bank \\
\hline Dep & The sum of Dep_old and Dep_young & WDI, The World Bank \\
\hline Life_exp & Years of life expectancy at birth & WDI, The World Bank \\
\hline Health & Public health expenditure as a share of GDP & WDI, The World Bank \\
\hline Inflation & $\begin{array}{l}\text { Annual percentage change of the consumer } \\
\text { price index }\end{array}$ & WDI, The World Bank \\
\hline Interest & $\begin{array}{l}\text { Lending interest rate adjusted for inflation } \\
\text { as measured by the GDP deflator }\end{array}$ & WDI, The World Bank \\
\hline Disclose & $\begin{array}{l}\text { Disclosure requirements imposed by } \\
\text { security laws }\end{array}$ & La Porta et al. (2006) \\
\hline Bdn_proof & $\begin{array}{l}\text { Liability standards facing security issuers } \\
\text { and intermediaries }\end{array}$ & La Porta et al. (2006) \\
\hline Dba_gdp & $\begin{array}{l}\text { Total claims of deposit money in banks on } \\
\text { domestic non-financial sectors as a share of } \\
\text { GDP }\end{array}$ & $\begin{array}{l}\text { Financial structure data set by Beck and } \\
\text { Demirgüç-Kunt. }\end{array}$ \\
\hline Savings & Ratio of gross savings to GDP & WDI, The World Bank \\
\hline M2_gdp & $\begin{array}{l}\text { Ratio of the broad definition of money } \\
\text { (M2) to GDP }\end{array}$ & WDI, The World Bank \\
\hline Secondary & Gross secondary enrollment ratio & WDI, The World Bank \\
\hline $\mathrm{Idv}$ & Hofstede's individualism index & Hofstede's website \\
\hline
\end{tabular}




\begin{abstract}
About the Authors
Chi Hung Chang is a PhD candidate at the Department of Finance at National Sun Yat-Sen University. His research interests are the development in financial and insurance markets and he has recently published in The Geneva Papers on Risk and Insurance-Issues and Practice, and Journal of Business Economics and Management.

Chien Chiang Lee is Associate Professor of Department of Finance at National Sun Yat-Sen University. His research areas include banking and insurance. He is an Associate Editor of Energy Economics and has recent publications in Journal of Money, Credit and Banking, Macroeconomic Dynamics, International Review of Economics and Finance, The Geneva Papers on Risk and Insurance-Issues and Practice, Journal of Financial Services Research, Urban Studies, Energy Economics, and Energy Journal.
\end{abstract}

